\title{
Mineral Resources of the Sleeping Giant Wilderness Study Area, Lewis and Clark County, Montana
}
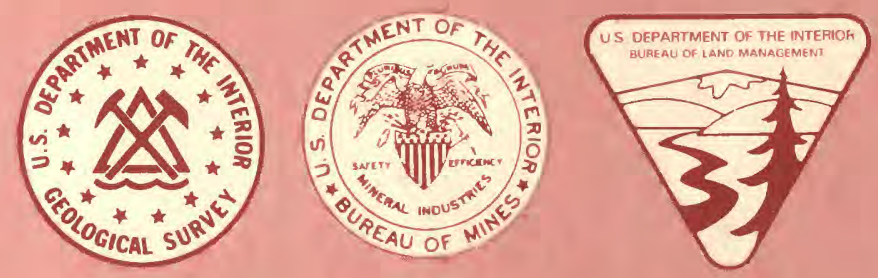

\section{U.S. GEOLOGICAL SURVEY BULLETIN 1724-E}

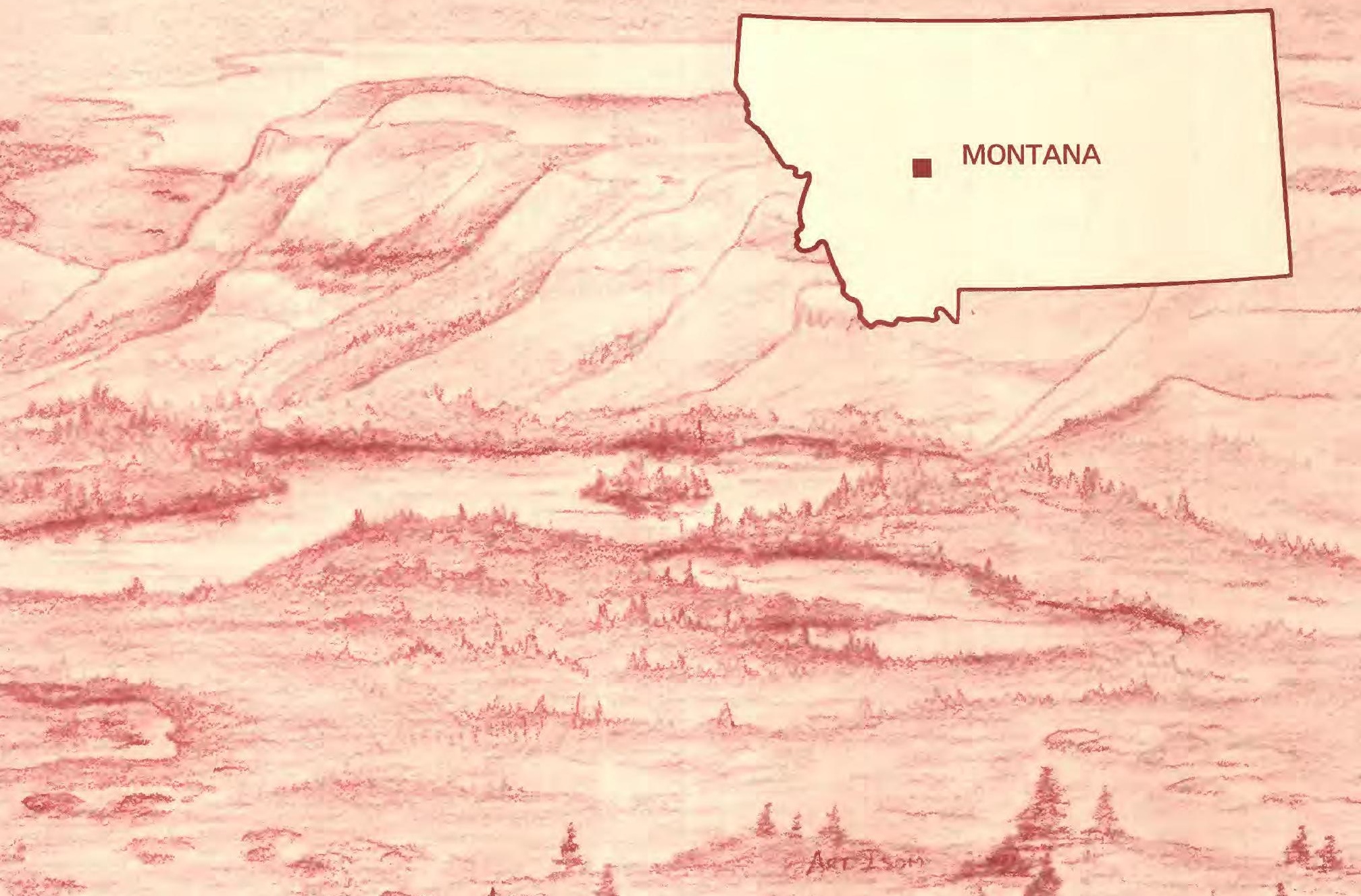



Chapter E

\section{Mineral Resources of the Sleeping Giant Wilderness Study Area, Lewis and Clark County, Montana}

By R.G. TYSDAL, M.W. REYNOLDS, R.R. CARLSON, M.D. KLEINKOPF, and L.C. ROWAN

U.S. Geological Survey

T.J. PETERS

U.S. Bureau of Mines 


\section{U.S. DEPARTMENT OF THE INTERIOR \\ MANUEL LUJAN, JR., Secretary}

U.S. GEOLOGICAL SURVEY

Dallas L. Peck, Director

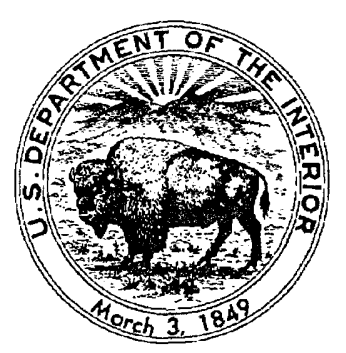

Any use of trade, product, or firm names in this publication is for descriptive purposes only and does not imply endorsement by the U.S. Government.

UNITED STATES GOVERNMENT PRINTING OFFICE: 1991

For sale by the

Books and Open-File Reports Section

U.S. Geological Survey

Federal Center

Box 25425

Denver, CO 80225

\section{Library of Congress Cataloging-in-Publication Data}

Mineral resources of the Sleeping Giant Wilderness Study Area, Lewis and Clark, County, Montana / by R.G. Tysdal ... [et al.]

p. cm. - (U.S. Geological Survey bulletin; 1724) (Mineral

resources of wilderness study areas-western Montana ; ch. E)

Includes bibliographical references ( $\mathrm{p}$. ).

Supt. of Docs. no.: । 19.3:1724E

1. Mines and mineral resources-Montana-Sleeping Giant Wilderness.

2. Sleeping Giant Wilderness (Mont.) I. Tysdal, R.G. (Russell G.)

II. Series. III. Series: Mineral resources of wilderness study areas-western Montana; ch. E.

QE75.B9

no. 1724-E

[TN24.M9]

$557.3 \mathrm{~s}-\mathrm{dc} 20$

$91-3932$

[553'.09786'615] 


\title{
STUDIES RELATED TO WILDERNESS
}

\author{
Bureau of Land Management Wilderness Study Areas
}

The Federal Land Policy and Management Act (Public Law 94-579, October 21, 1976) requires the U.S. Geological Survey and the U.S. Bureau of Mines to conduct mineral surveys on certain areas to determine the mineral values, if any, that may be present. Results must be made available to the public and be submitted to the President and the Congress. This report presents the results of a mineral survey of the Sleeping Giant Wilderness Study Area (MT-075-111), Lewis and Clark County, Montana. 


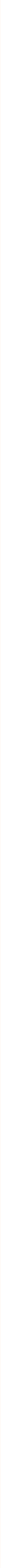




\section{CONTENTS}

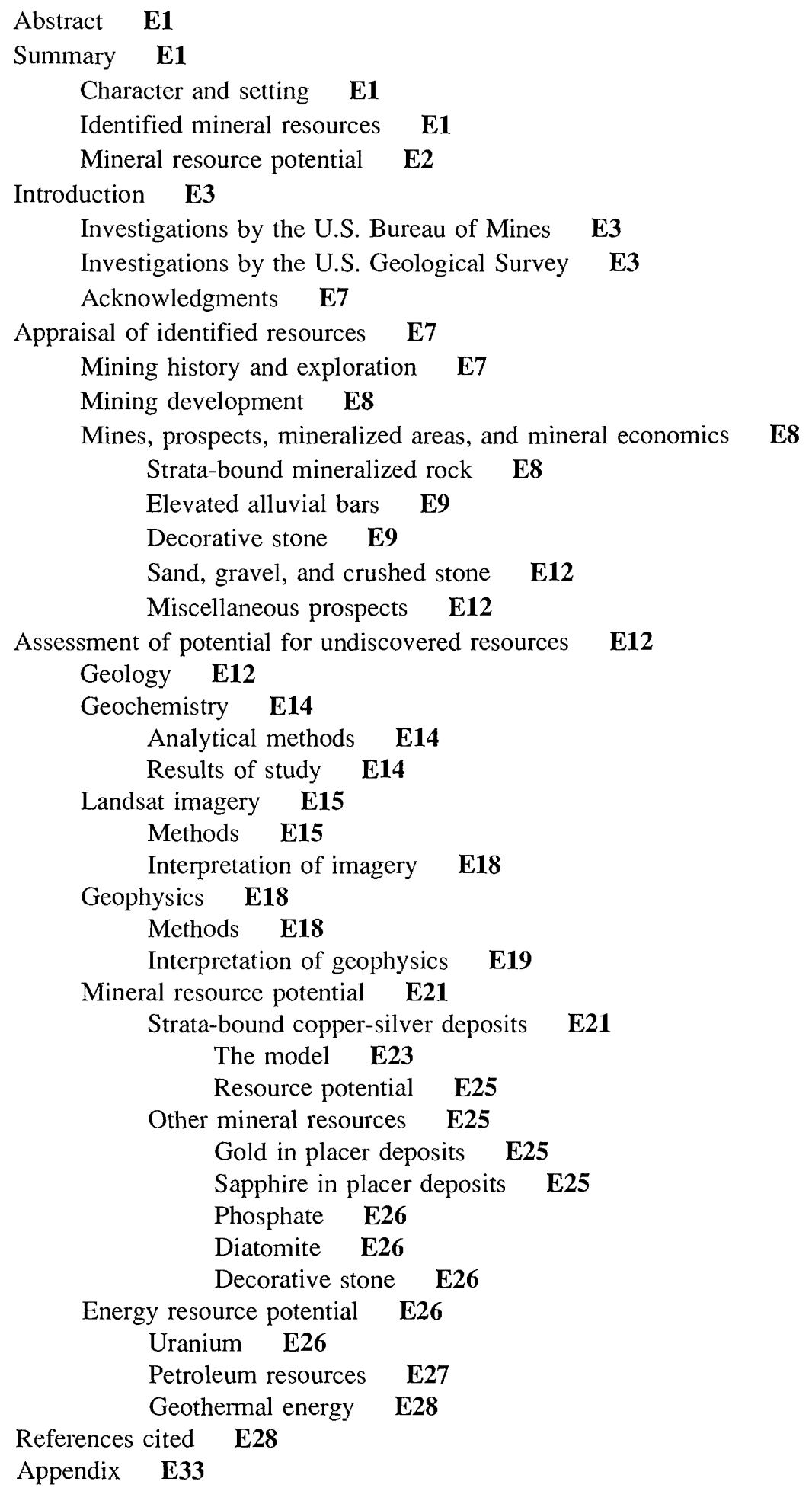




\section{PLATE}

[Plate is in pocket]

1. Maps showing the mineral resource potential, geology, sample localities, and limonitic alteration of Sleeping Giant Wilderness Study Area

\section{FIGURES}

1. Map showing location of Sleeping Giant Wilderness Study Area, Lewis and Clark County, Montana E2

2. Map showing generalized geology, mineral resource potential, and prospects E6

3. Diagram of reflectance spectra for limonitic rock E18

4. Map showing terrain-corrected Bouguer gravity anomalies and generalized geology E20

5. Map showing aeromagnetic anomalies and generalized geology

\section{TABLES}

1. Sequence of geologic units $\mathbf{E} \mathbf{4}$

2. Mines, prospects, and mineralized areas $\mathbf{E 1 0}$

3. Semiquantitative spectrographic and chemical analyses of rock samples E16

4. Vitrinite reflectance and pyrolysis of shale

E27 


\title{
Mineral Resources of the Sleeping Giant Wilderness Study Area, Lewis and Clark County, Montana
}

\author{
By R.G. Tysdal, M.W. Reynolds, R.R. Carlson, M.D. Kleinkopf, and L.C. Rowan \\ U.S. Geological Survey
}

T.J. Peters

U.S. Bureau of Mines

\section{ABSTRACT}

A mineral resource survey was conducted in 1987 by the U.S. Geological Survey and the U.S. Bureau of Mines to evaluate mineral resources (known) and mineral resource potential (undiscovered) of the Sleeping Giant Wilderness Study Area (MT-075-111) in Lewis and Clark County, Montana. The only economic resource in the study area is an inferred 1.35-million-ton reserve of decorative stone (slate); a small gold placer resource is subeconomic. A high resource potential for decorative slate exists directly adjacent to the area of identified slate resource and in the northeastern part of the study area. The rest of the study area has a low potential for decorative slate. The westernmost part of the study area has a moderate resource potential for copper and associated silver in strata-bound deposits in green beds and limestone; potential is low in the rest of the study area. The study area has a low resource potential for sapphires in placer deposits, gold in placer deposits (exclusive of subeconomic resource mentioned above), phosphate in the Spokane Formation, diatomite in lake deposits, uranium, oil, gas, geothermal energy, and no resource potential for phosphate in the Phosphoria Formation.

\section{SUMMARY}

\section{Character and Setting}

The Sleeping Giant Wilderness Study Area, also referred to here as the "study area" or "the area," is in west-central Montana about $20 \mathrm{mi}$ (miles) north of the capitol city of Helena and about $4 \mathrm{mi}$ south of the town of Wolf Creek (fig. 1). The

Manuscript approved for publication March 15, 1991. study area is mountainous with elevations that range from about 3,600 to $6,800 \mathrm{ft}$ (feet). The western part of the area is accessible from a "jeep" road that connects with an access road adjacent to Interstate Highway 15, 1-2 mi west of the study area. The eastern part of the area is accessible by boat from Holter Lake, which abuts much of the eastern boundary of the study area. The interior part has limited access from a maintenance road along a narrow corridor for a power line that exists between the two parts of the study area

Rocks that crop out in the study area range from Middle Proterozoic to Cretaceous in age (table $1 ;$ pl. 1). Siltite and argillite of the Middle Proterozoic Belt Supergroup make up most of the rocks exposed within the study area. Rocks that crop out in the easternmost part of the study area are mainly Cretaceous in age and are composed of sandstone, siltstone, and shale; felsic to mafic sills; and interbedded welded tuff, lava, and clastic strata. These rocks dip generally westward at moderate angles. The Middle Proterozoic strata have been displaced northeastward along a major low-angle thrust fault, the Eldorado thrust, and are juxtaposed over younger strata concealed beneath the study area.

\section{Identified Mineral Resources}

An inferred economic reserve of 1.35 million tons of decorative iron- oxide-stained, slate facing stone occurs on the Sperry claim group (loc. (locality) 8, fig. 2, table 2, pl. 1). A subeconomic gold resource is inferred within $380,000 \mathrm{yd}^{3}$ (cubic yard) of gravel in elevated alluvial bars at a grade of $0.0032 \mathrm{oz}$ (ounce) gold per $\mathrm{yd}^{3}$ (loc. 6, fig. 2, table 2, pl. 1), worth $\$ 1.52$ per yd $\mathrm{d}^{3}$ at a $\$ 475$ per oz gold price. Copper and silver in strata-bound occurrences (locs. 4 and 5, fig. 2, table 2, pl. 1) are too low grade to be mined within the foreseeable future. No energy resources were identified. 


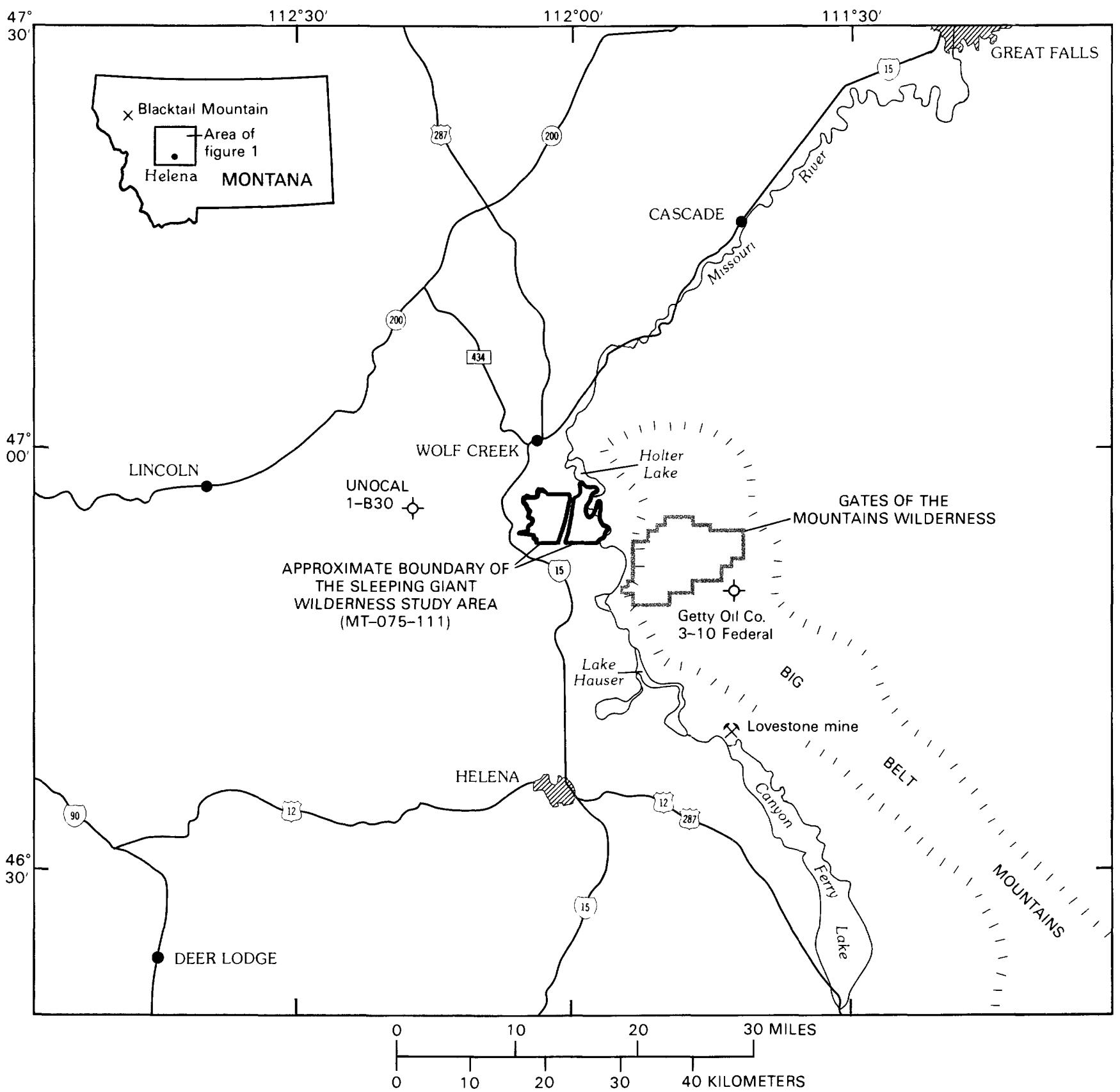

Figure 1. Index map showing location of the Sleeping Giant Wilderness Study Area, Lewis and Clark County, Montana.

\section{Mineral Resource Potential}

A high resource potential exists for decorative stone (slate) in the Middle Proterozoic Greyson Formation directly adjacent to the identified resource of slate and in the northeastern part of the Sleeping Giant Wilderness Study Area. The remainder of the formation in the study area has a low resource potential for building stone. Within the westernmost part of the study area, green beds (siltite and argillite) and limestone of the Middle Proterozoic Spokane Formation have a moderate resource potential for strata-bound copper and silver. The remainder of the Spokane Formation in the study area has a low resource potential for strata-bound copper and silver; other formations have no resource potential for this deposit type.

Sediments (unconsolidated materials) deposited along the course of the Missouri River have a low mineral resource potential for placer deposits of gold (exclusive of the identified placer resource described in the previous section) and sapphires. A thin bed of phosphate-bearing rock occurs in the Spokane Formation west of the wilderness study area; a low resource potential exists for phosphate in strata of the Spokane 
Formation within the study area. A low mineral resource potential exists for diatomite in unconsolidated lake deposits preserved along the Missouri River. A low resource potential exists for uranium in sedimentary and igneous rocks, for oil and gas, and geothermal energy within strata above or below the Eldorado thrust fault. The Lower Permian Phosphoria Formation lacks phosphate-bearing strata where it crops out in the general region and the formation is rated as having no resource potential for phosphate in the study area.

\section{INTRODUCTION}

The Sleeping Giant Wilderness Study Area (MT-075-111) encompasses 15,174 acres that were studied by the U.S. Geological Survey (USGS) and the U.S. Bureau of Mines (USBM) at the request of the U.S. Bureau of Land Management (BLM). The study area is in west-central Montana, about 20 mi north of the capitol city of Helena and about $4 \mathrm{mi}$ south of the hamlet of Wolf Creek (fig. 1). Mountainous terrain of Lewis and Clark County underlies the area, which ranges from about 3,600 to $6,800 \mathrm{ft}$ in elevation. When viewed from the south, the profile of the mountains appears to be that of a sleeping giant. Igneous rocks in the rugged easternmost part of the area form the head, which features an especially prominent nose, and sedimentary strata of the remainder of the area form the chest and belly. Access to the western margin of the area can be gained by a "jeep" road that extends from an access road adjacent to Interstate Highway 15, 1-2 mi west of the study area. The eastern part of the area is accessible by boat from Holter Lake, a manmade reservoir created by a dam on the Missouri River, which forms much of the eastern boundary of the study area. Limited access is available from a maintenance road along a power line corridor between the two parts of the wilderness study area.

Field and laboratory studies were conducted to assess the mineral resource potential of the study area. Limited geologic mapping was undertaken to supplement that done previously, and gravitational data were collected within and immediately adjacent to the study area. A geochemical study was undertaken and was based on spectrographic and wet-chemical analyses of rocks, stream-sediment, and heavy-mineral concentrate samples collected by the USGS. The USBM examined and sampled prospects and mineral occurrences.

This report presents an evaluation of the mineral resource endowment (identified resources and mineral resource potential) of the study area and is the product of several separate studies by the USBM and the USGS. Identified resources, studied by the USBM, are classified according to the system of the U.S. Bureau of Mines and U.S. Geological Survey (1980), which is shown in the Appendix of this report. Mineral resource potential is the likelihood of occurrence of undiscovered metals and nonmetals, industrial rocks and minerals, and of undiscovered energy sources (uranium, coal, oil, gas, oil shale, and geothermal sources). It is classified according to the system of Goudarzi (1984) and is shown in the Appendix of this report. Classification is according to type of deposit, level of potential, and level of certainty. The mineral resource potential for undiscovered resources is studied by the USGS. In this report, the term "deposit," unmodified, carries no connotation of economic value.

The present report on the mineral resources of the Sleeping Giant Wilderness Study Area was released originally as a USGS Open-File Report (Tysdal and others, 1990) to make the data available for immediate use. The present report contains no changes in the reserves, subeconomic resources, or the ratings of mineral resource potential presented in the open-file report. Editorial changes have been made for conformity with USGS editorial standards and for conformity with currently accepted stratigraphic nomenclature.

\section{Investigations by the U.S. Bureau of Mines}

The USBM examines individual mines, prospects, claims, and mineralized zones, and evaluates identified mineral and energy resources. The present study included prefield, field, and report-preparation phases. The prefield phase included a library search of geological and mining literature. BLM master title plats, current mining-claim recordation data, and Lewis and Clark County mining claim notices were perused to search out all mineral properties and property owners.

Field work was conducted during June and July, 1987. A search was conducted for mine and prospect workings. Mineralized sites inside and within $1 \mathrm{mi}$ of the study area were examined, mapped, and sampled. The Anson and Blue Slate patented stone claims outside the southern boundary of the study area (locs. 9 and 11, fig. 2, table 2, pl. 1) were not evaluated; likewise, logistical and time constraints precluded study of Ming Bar (loc. 12, fig. 2 , table 2, pl. 1), also outside and south of the study area. In some places, bedded mineralized rock was sampled more than $1 \mathrm{mi}$ from the study area boundary, where beds appeared to project into the study area.

\section{Investigations by the U.S. Geological Survey}

During the summer of 1987 , stream-sediment and heavy-mineral concentrate samples were collected from streams that drain the study area and were analyzed chemically and spectrographically. Selected rock samples were collected and analyzed by the same methods to aid in 


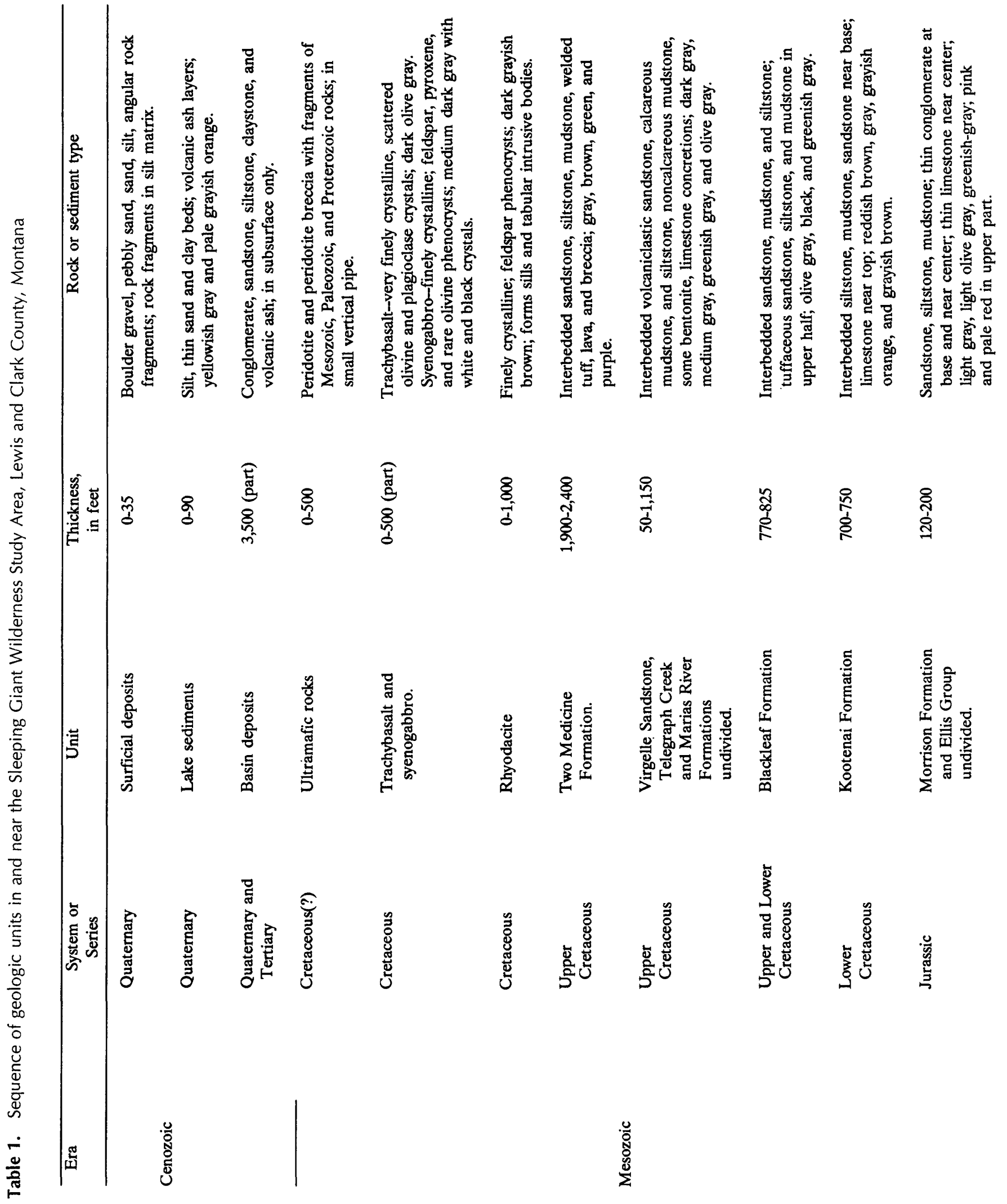




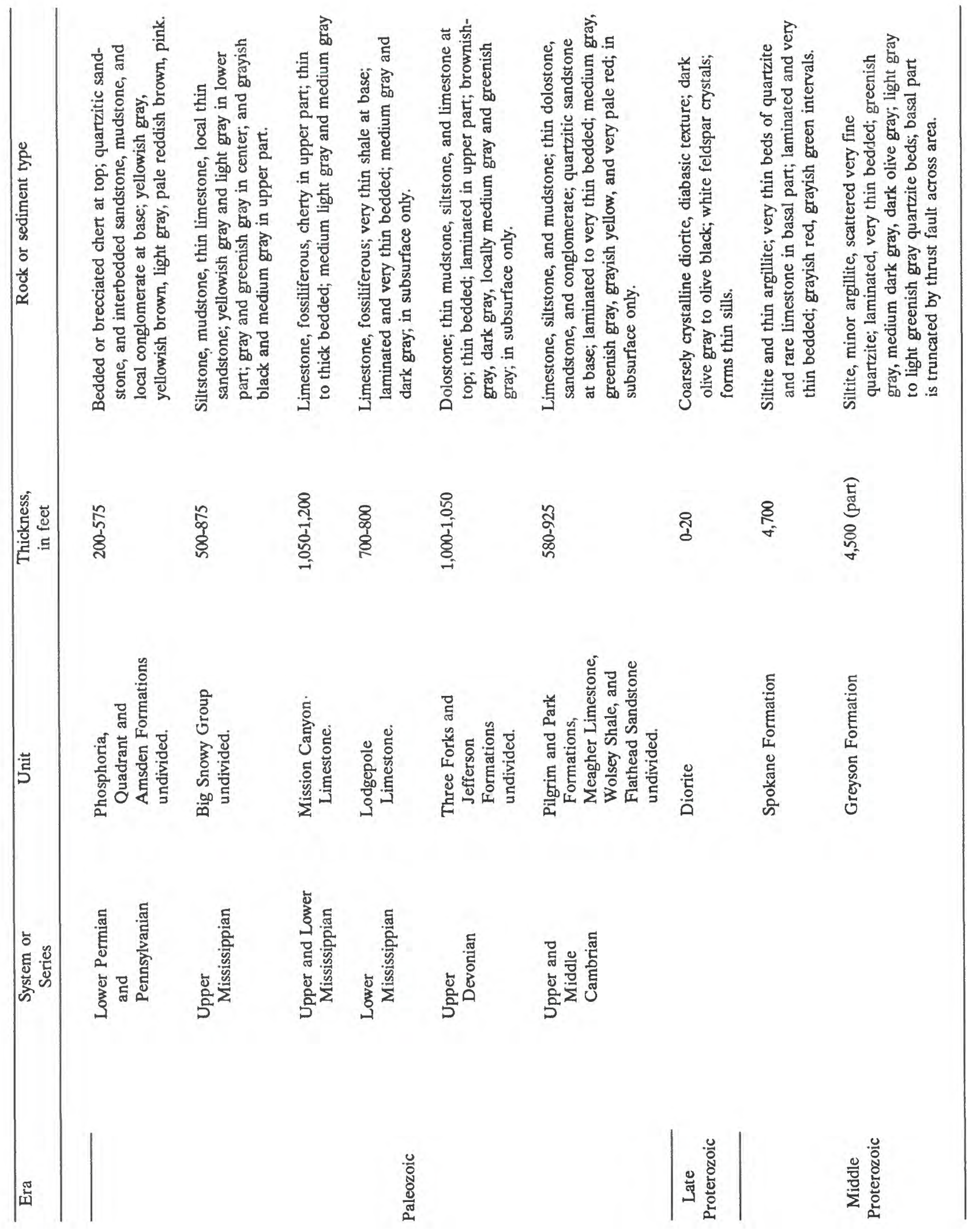




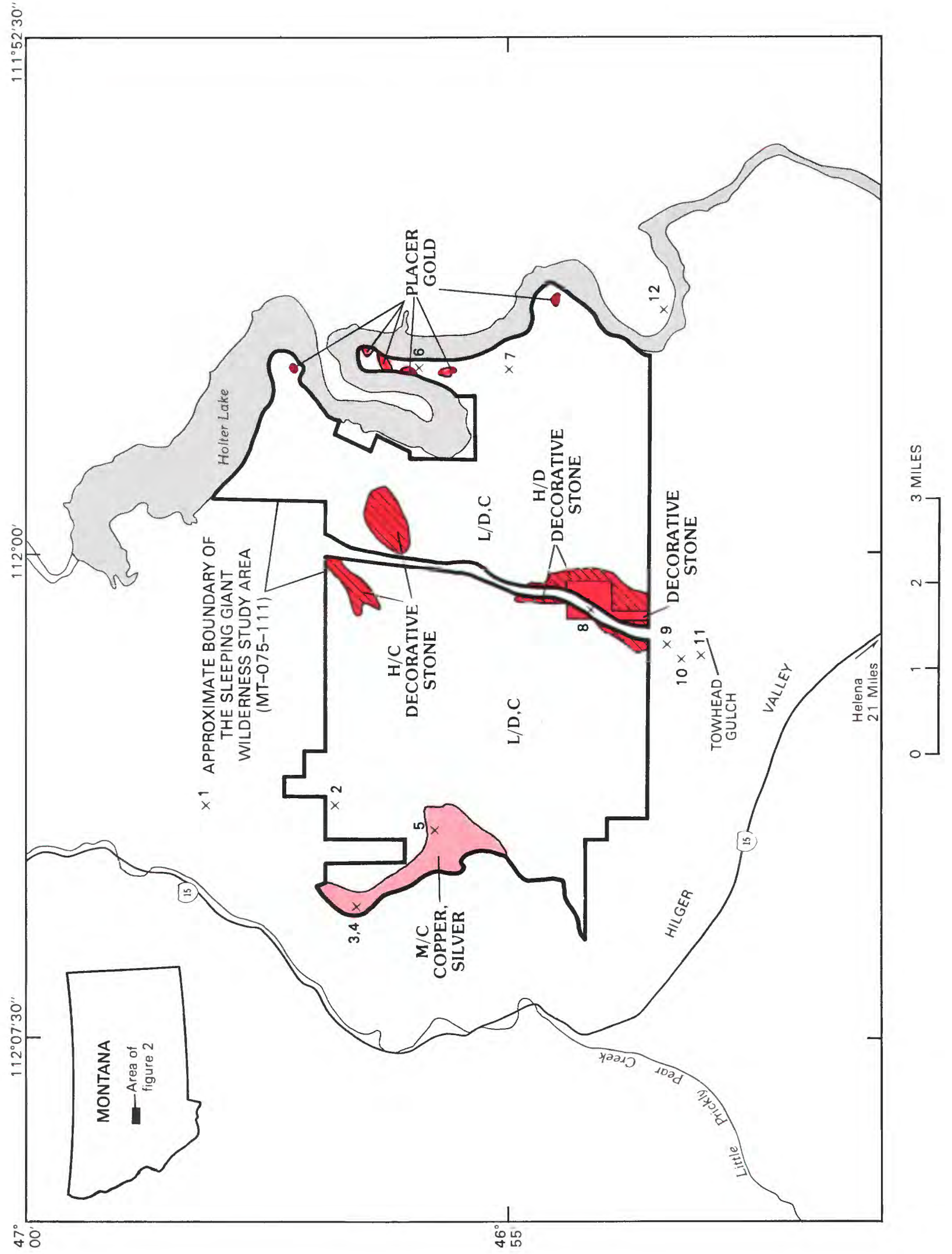




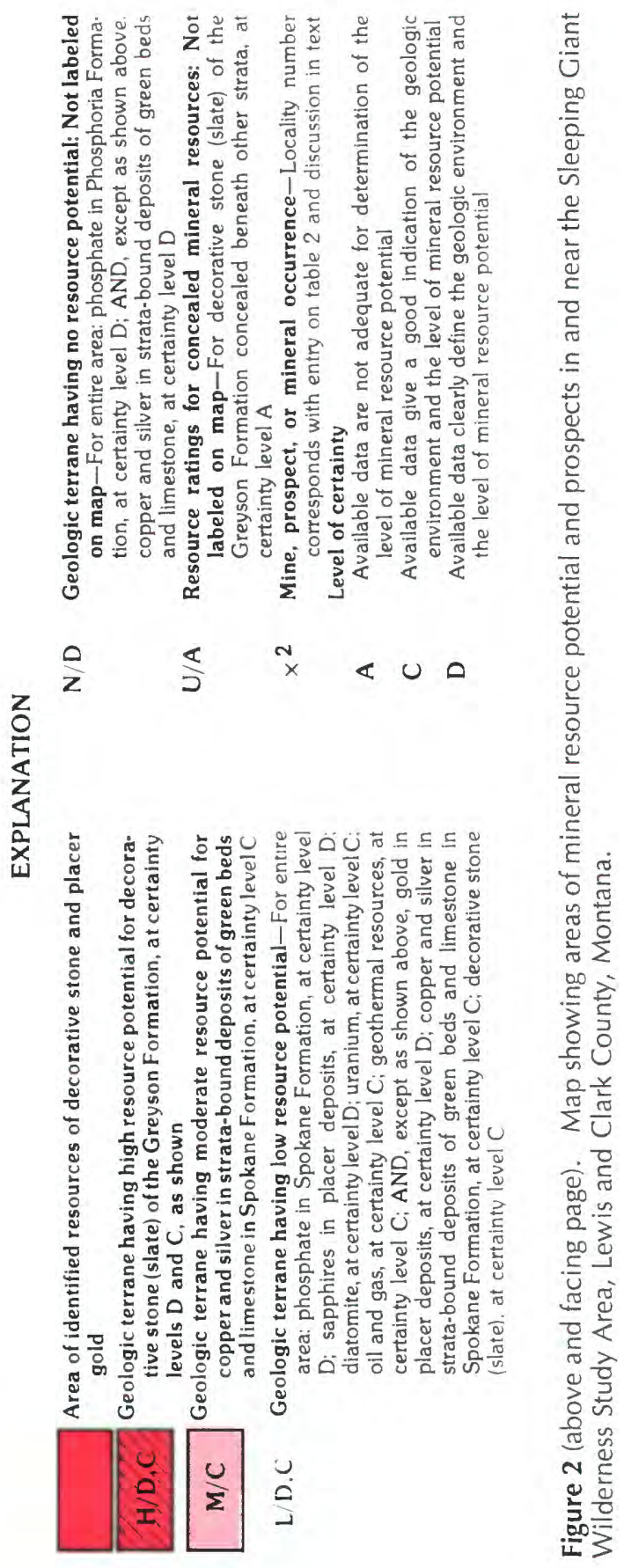

the interpretation of the stream-sediment and concentrate data. New gravity measurements were made in and adjacent to the study area. New geologic mapping was conducted in the western part of the study area, and locally within the eastern part to supplement mapping of Robinson and McCallum (1991).

\section{Acknowledgments}

The authors are grateful to Howard and Merinell Anson, owners, and Robert Williams, operator, of the Anson claim group, and to Edward Sperry, owner of the Sperry claim group, for their help, and for essential information regarding their slate deposits. Jerry Lorbeck, owner of the Lovestone Sapphire mine near Canyon Ferry, Mont., provided needed information on elevated Missouri River alluvial bars. Tim M. and Betty Babcock, Oxbow Ranch, and John Baucus, Jr., Sieben Ranch, provided information on, and allowed access across, their property. Richard M. Clark and David Walter, Montana Historical Society, Helena, provided historical perspective.

Information on mineralization of Belt Supergroup strata was provided by Eric R. Braun, geological consultant, and Ian Lange, University of Montana, Missoula; Henry McClernan, Montana School of Mines, Butte; Jan Krason, Geoexplorers International, Denver, Co.; and Herb Bradshaw, geological consultant, Spokane, Wash. Land status and logistical information was provided by Dave Williams, BLM, Butte, Mont.

The eastern part of the geologic map of plate 1 was generalized from the map of Robinson and McCallum (1991). Their work was supplemented by new USGS mapping in areas critical to structural interpretation and resource evaluation.

\section{APPRAISAL OF IDENTIFIED RESOURCES}

\section{By T.J. Peters \\ U.S. Bureau of Mines}

\section{Mining History and Exploration}

The earliest recorded prospecting activity in the vicinity of the Sleeping Giant Wilderness Study Area was several miles northwest in the Wolf Creek mining district for copper, silver, and gold in 1881 (Lewis and Clark County mining records). The Wolf Creek activity extended southeast into the Sheep Creek drainages in April 1887, with location of the Sheep Creek mine by Hannibal Robertson, about $1 \mathrm{mi}$ north of the study area (loc. 1, fig. 2, table 2, pl. 1). The Ravenwood claim, located in 1886 , may be the prospect northeast of Beartooth Mountain (loc. 7, fig. 2, table 2, pl. 1). 
Prospecting history of strata-bound copper-silver mineralized rock probably began in the middle 1970 's. It is almost certain that little attention was given to the mineralized rock prior to the middle 1960 's, when awareness of strata-bound copper in Belt Supergroup rocks became widespread. Strata-bound copper was observed within a 0.08 -ft-thick phosphorite bed, in light-green Spokane Formation siltite, in a new roadcut in Wolf Creek Canyon by Gulbrandsen (1966, p. D199-D201). In November, 1976, Harvey B. Straude located a claim over the north canyon wall of Spring Gulch west of the study area, where copper-bearing green siltites crop out. In June, 1977, Ed and Robert Leo Zitnik and Kenneth and Edward Schmaus located claims west of the study area covering parts of the mineralized rock reported by Lange and Eby (1981). It is not certain who excavated a shallow 4-ft-wide by 4-ft-long pit in green siltite at the head of Bear Gulch in the western part of the study area (loc. 5, fig. 2, table 2, pl. 1).

A surge of placer claim activity began in 1891 and continued until 1906 along the stretch of the Missouri River between Ming Bar and Holter dam, which borders the eastern side of the study area. During the 15-year period, more than seventy-five 160 -acre association placer claims were located or relocated along the river by pioneer families, such as Sperry (Sperry Ranch) and Rickey (Oxbow Ranch), who settled in the vicinity of the study area. Frank D. Spratt, a claimant on an 1892 claim in the study area, previously had interests in Eldorado Bar, a large bar perched above the northeast bank of the Missouri River about $20 \mathrm{mi}$ upstream. Spratt and fellow claimants sold 4,000 acres of Eldorado Bar to the British-owned Montana Sapphire and Ruby Co., Ltd., in about 1889 (Mertie and others, 1951, p. 90). The ancient alluvium perched above the Oxbow Canyon (loc. 6, fig. 2, table 2, pl. 1) probably was mined during 1891-1906. Ming Bar (loc. 12, fig. 2, table 2, pl. 1), northernmost of the large Missouri River elevated bars, was actively worked during that time.

\section{Mining Development}

Slate has been quarried since 1906 from placer claims along Towhead Gulch by the Anson family and associates, a consortium orginally known as the Atlas Slate Company. Atlas slate was used in many Helena buildings, including the State Capitol and Carroll College (Wirth, 1985, p. 2). The family's Blue Slate claim (loc. 11, fig. 2, table 2, pl. 1) was patented in 1918. A mill on the claim produced shingles and blackboards in the 1920's, 1930's, and 1940's, but is no longer usable. The Anson Nos. 1 and 2 (pl. 1, loc. 9) claims were located in August, 1977, and patented in 1985. Earlier claims by the Anson family on the same quarter section go back to 1906. Robert Williams, Helena, Mont., has operated the Anson quarries for several years and produces about 1,000 tons of facing-stone slate per year.
Edward Sperry located 10 placer stone claims (loc. 8, fig. 2, table 2, pl. 1), in September 1977. Mr. Sperry was not operating his quarries at the time of this study, but he reported 1,200 tons of facing-stone production during his tenure on the claims.

According to BLM records, oil and gas leases obtained to search Montana disturbed belt structures for oil and gas traps (see Maher, 1976) are dispersed across the study area.

\section{Mines, Prospects, Mineralized Areas, and Mineral Economics}

There are seven mines, prospects, or mineralized areas within the Sleeping Giant Wilderness Study Area (locs. 2-8, fig. 2, table 2, pl. 1) and five more mineral occurrences or properties are within $1 \mathrm{mi}$ of the study area boundary (locs. 1 and 9-12, fig. 2, table 2, pl. 1). Information about the localities is summarized in table 2 .

\section{Strata-bound Mineralized Rock}

Two occurrences (locs. 4 and 5, fig. 2, table 2, pl. 1) and several nearby beds contain strata-bound copper-silver minerals and represent mineralized areas. Locality 4 has copper-silver minerals within quartzite (metamorphosed sandstone) and was found during this study. Locality 5 represents mineralized green siltite (metamorphosed siltstone, with minor limestone). Mineralized rocks were reported west and south of the study area (Lange and Eby, 1981; Lange and others, 1986; Lange and others, 1987) and were found to extend into the area during the present study. Several other green siltite units that contain minor copper and silver were also examined.

Copper-and silver-bearing quartzite.-A 1.7-ft-thick gray quartzite within the fairly arenaceous upper part of the Spokane Formation (as it is represented within the study area) crops out in the northwest corner of the study area between red siltite and red quartzite facies (loc. 4, fig. 2, table 2, pl. 1). A small mineralized area is inferred, but no resources are identified because of small size and low grade. The northwest-dipping quartzite projects beyond the study area to the northwest, where the copper and silver content and thickness of the mineralized rock are unknown; the quartzite is near the surface of the ground there along the west-dipping slope of Little Prickly Pear Canyon. The copper and silver content and thickness of the mineralized quartzite outside the study area were not determined. The occurrence may be genetically similar to the sandstone-type of mineralized rock described by Braun and Lange (1984) and Lange and others (1986) in their Upper Spokane Formation "Transition Zone" along the continental divide between Flesher and Rodgers Passes, about 15 mi east and northeast, respectively, of Lincoln, Mont. (fig. 1). The copper-silver minerals there are in 100 - to 130 -ft-thick arenaceous beds and have economic potential. 
Copper-and silver-bearing siltite and limestone.Copper and silver are concentrated in several green siltite units within the Spokane Formation inside and west of the study area (loc. 5, fig. 2, table 2, pl. 1). The USBM tentatively and informally identified four rock units. The main green siltite unit commonly includes the thin mineralized limestone bed described by Lange and others (1986) and Lange and others (1987). The sequence sampled in the present study includes the weakly mineralized overlying and underlying siltite, because any possible exploitation would require moving siltite as well as limestone, and because the rock unit is easily defined in the field.

The main rock unit extends east into the study area at Bear Gulch (pl. 1) and crops out intermittently along a 3,000-ft-long trace on the northwest side of the gulch, where sequences were sampled across the zone at three sites (Peters and Winters, 1988, fig. 5). The unit was also sampled on the northwest side of Bear Gulch from an outlier $0.6 \mathrm{mi}$ southwest of the study area. Three sets of samples were taken from outcrops reported by Lange and others (1987, p. 1337). At least three minor green siltite units were also sampled but contained less than 100 ppm (parts per million) copper.

Although the copper-silver minerals are not economic, sample analyses (Peters and Winters, 1988, table A-1) may help understand the distribution of elements in Belt Supergroup terrane (Peters, 1989). The mineralized green siltite (with minor limestone) units make up less than 2 percent of the Spokane Formation, but contain about 200 times the concentration of copper found in red argillaceous siltite, which comprises the bulk of the formation.

An approximate weighted average of all chip samples from the main rock unit, including both green siltite and limestone, is $385 \mathrm{ppm}$ copper or about 0.04 percent. Silver values average about $0.77 \mathrm{ppm}$ or $0.02 \mathrm{oz} /$ ton (troy ounce per ton). The strata-bound copper- and silver-bearing siltite and limestone are not considered resources because of low grade, which is at least 10 times lower than at present operating mines.

\section{Elevated Alluvial Bars}

Seven small, elevated, alluvial Missouri River bars contain placer gold. Gold-bearing gravel in the bars looks like gravel on major elevated bars upstream, such as goldand sapphire-bearing gravel at the Lovestone mine on Gruel Bar about 25 mi upstream near Canyon Ferry Lake (fig. 1); sapphires were not found in gravels within the study area. Ming Bar (loc. 12, fig. 2, table 2, pl. 1), farthest north of the major elevated Missouri River bars, was not examined during this study, but is discussed briefly by Lyden (1948, p. 68). At the largest cluster of workings (loc. 6, fig. 2 , table 2, pl. 1), an estimated $1,400 \mathrm{yd}^{3}$ of gravel had been mined. Based on analyses of five samples, the weighted average gold content (assumed 1,000 fineness) of the mined gravel was $0.016 \mathrm{oz} / \mathrm{yd}^{3}$, indicating past production was only worth about $\$ 460$, at a pre-1934 gold price of $\$ 20.67$ per ounce.

All the bars in the study area appear to have a maximum thickness of about $10 \mathrm{ft}$, but probably average 6 $\mathrm{ft}(2 \mathrm{yds})$ thick and pinch out along the margins. The seven elevated bars total about 40 acres (or about 190,000 $\mathrm{yd}^{2}$ (square yards)) for a total cubic yardage of 380,000 . The average gold content was 0.0032 troy ounces per yard, worth $\$ 1.52$ per cubic yard at a $\$ 475$ per ounce gold price. However, all the samples worth more than $\$ 1.60$ per cubic yard were from one sample site (Peters and Winters, 1988, table A-2). Maximum value at the site was about $\$ 12$ per cubic yard from a 2.5 -ft-long sample. Gravel bars contain an inferred subeconomic resource because the average value of the gravel is much less than an estimated mining cost of $\$ 7$ per cubic yard (methods of Benjamin and Gale, 1984 (January 1988, costs)), and because gold-rich gravels appear to be local.

\section{Decorative Stone}

Although slate (the lower unit of the Greyson Formation) from Towhead Gulch has been used historically for many dimension-stone applications, the only marketable application for the past 30 years has been as decorative facing stone. Stone use is expected to expand in the future (Taylor, 1985, p. 775, and 1988, p. 153). Decorative facing stone is an enduring and architecturally adaptable material.

Resource evaluation in this report is limited to the Sperry claim group (loc. 8 , fig. 2, table 2, pl. 1), which is inside the study area, and to a few comments on the Anson No. 3 (loc. 10, fig. 2, table 2, pl. 1), which is outside the study area. The Anson-Williams operation is south of the study area, primarily on patented land, and was evaluated in Mineral Patent Examination Report M-50642 (Wirth, 1985). No patented claims (locs. 9 and 11, fig. 2, table 2, pl. 1) were evaluated during the present study. Additional stone resources suitable as facing material undoubtedly occur on unclaimed land of the study area underlain by the lower unit of the Greyson Formation. There are, however, ample resources on the Anson and Sperry properties to meet requirements for the foreseeable future.

Sperry stone claims.- The Sperry quarries are inside the study area and were not operating at the time of this study, but Edward Sperry reported total production from the 10-year-old claim group to be about 1,200 tons, most of which was marketed in central and western Washington State. The iridescent red, yellow, and brown iron-oxidestained slabs make an ideal indoor facing-stone product for building lobbies, den walls, fireplaces, and stove pads. Although not useful for floors or patios, the material should also be suitable for outdoor walls and chimneys; Mr. Sperry said the iron-oxide stains will wear off if walked on, but do 


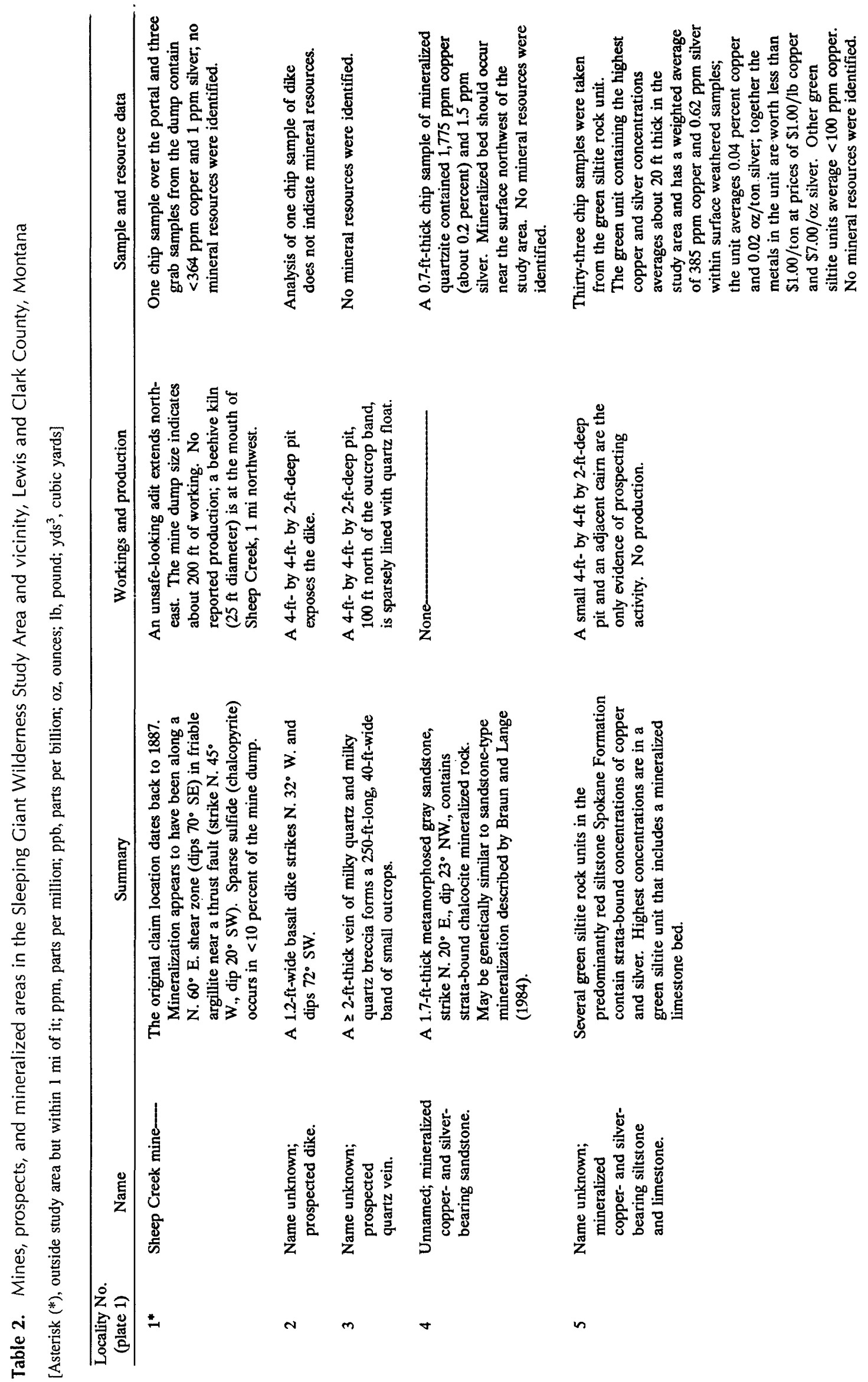




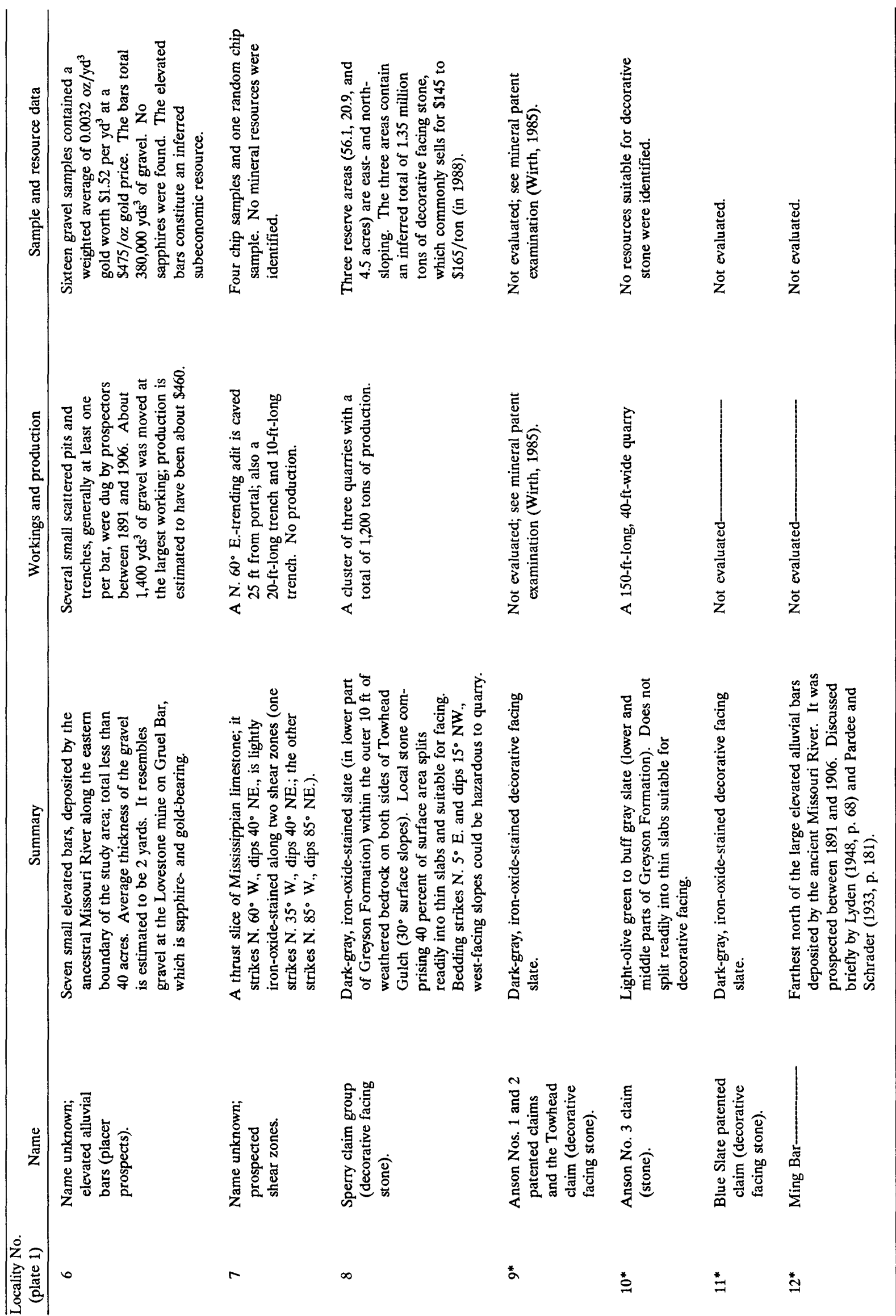


not normally wash off from vertical outside surfaces. About 85 percent of the stone product is iron-oxide stained, 10 percent is gray, and 5 percent is bluish silver. Thinner slate slabs are more valuable because they can cover more surface.

Marketability and minability are related to two factors controlled by surface weathering of the rock: (1) iron-oxide stains along splitting planes, parallel to bedding, and (2) how readily the rock splits along the planes. Rock that has both these qualities is typically only the top 10-ft-thick zone of weathered (but uneroded) bedrock. Another criterion, based on quarrying experience, is that only 40 percent of the weathered zone splits readily.

Bedding orientation is remarkably consistent where the stone is a resource in the study area. The stone most commonly strikes N. $5^{\circ}$ E. and dips $15^{\circ} \mathrm{W}$. The bedding (and splitting plane) orientation result in potentially hazardous mining conditions on the west-facing east slope of Towhead Gulch: there the slope has a strike similar to that of the bedding but is $15^{\circ}$ steeper. Quarrying into the west-sloping hillside could further destabilize the slope.

Five resource blocks are inferred on the Sperry claim group (Peters and Winters, 1988, fig. 9). The map area of the blocks was measured and multiplied by a factor of 1.15 to allow for extra surface area, due to slope of hillsides. Forty percent of the map area within the blocks was estimated to be underlain by stone suitable for facing to a thickness of $10 \mathrm{ft}$; a tonnage-volume factor of $12.1 \mathrm{ft}^{3}$ (cubic feet) per short ton was used.

In three of the five resource blocks, the rock slope is nearly perpendicular to the dip slope: an east-sloping block of 56.1 acres, west of Towhead Creek, and two smaller north-sloping blocks, 20.9 and 4.5 acres, along small drainages east of the creek. These three blocks contain total minable inferred economic reserves (U.S. Bureau of Mines and U.S. Geological Survey, 1980) of 1.35 million tons of decorative facing stone. The two remaining of the five blocks, 64.0 and 47.5 acres, are susceptible to rock slides because the beds dip parallel to the slope. These hazardous blocks contain an inferred 1.85 million tons of decorative stone; the blocks should not be considered inferred reserves, however, because safety factors put recoverability in doubt.

Production costs, minimum acceptable profit, and markets dictate the price of decorative stone. Production is labor-intensive. Stone is quarried by ripping with a bulldozer or backhoe; blasting breaks up the stone, destroying the product. The stone is hand-split, loaded onto pallets, and shipped. Estimated quarrying costs for facing stone at the Sperry claims is about $\$ 100$ per ton (Edward Sperry, oral commun., 1987).

Seventy-five percent of the facing stone occurs as slabs $0.04 \mathrm{ft}$ thick or less and worth $\$ 165$ per ton, and 25 percent is about $0.06 \mathrm{ft}$ thick and worth $\$ 145$ per ton. Because the value exceeds estimated costs by more than 30 percent, the facing stone on the Sperry claims is classified as an inferred economic reserve.

Anson No. 3 claim.-This claim was examined briefly (loc. 10, fig. 2, table 2 , pl. 1). Stone in the quarry looks considerably different from stone along the bottom of Towhead Gulch and appears to be the lower unit of the Greyson Formation. The stone was light olive green to buff gray, commonly had alternate light and dark laminae, and had silt- or fine-sand-size clastic interbeds. The material did not split cleanly, when it split at all, and its usefulness for facing stone is doubtful.

\section{Sand, Gravel, and Crushed Stone}

Sand and gravel in unconsolidated deposits that could be used for road construction are present mainly in the eastern part of the study area, in remote terrace deposits perched above the Missouri River. Deposits of similar materials are widespread in the vicinity of the study area and are more readily accessible. The entire study area is underlain by rock that could be crushed and sized for road construction purposes, but similar rock materials are widespread outside the study area as well.

\section{Miscellaneous Prospects}

Four localities in the study area were apparently prospected for metallic lodes because of minor or suspected mineralization associated with dikes, quartz veins, or shear zones (locs. 1-3, 7, fig. 2, table 2, pl. 1). These prospects are summarized in table 2 and are not discussed here because of low grade, small size, and the apparent lack of mineral resources.

\section{ASSESSMENT OF POTENTIAL FOR UNDISCOVERED RESOURCES}

\author{
By R.G. Tysdal, M.W. Reynolds, \\ R.R. Carlson, M.D. Kleinkopf, and \\ L.C. Rowan \\ U.S. Geological Survey
}

\section{Geology}

The Sleeping Giant Wilderness Study Area lies near the eastern edge of the Montana disturbed belt where the trend of the belt changes from north-northwest to southeast. Thrust faults of the belt juxtapose rock types of contrasting age and character from north-northwest to south-southeast across the eastern edge of the study area. Five generalized rock sequences are exposed. Rock units that comprise the sequences are described briefly in table 1 and are shown on plate 1. 
1. West from both the saddle on Beartooth Mountain and the Oxbow bend of the Missouri River, about 9,200 $\mathrm{ft}$ of Middle Proterozoic strata are exposed at the surface. These strata belong to the Greyson Formation below in the east and the Spokane Formation above in the west. The Greyson consists of laminated and very thin bedded dark gray, olive black, and olive gray siltite and silty argillite, with light gray and greenish gray quartzite beds at the top. The overlying Spokane Formation is a thick sequence of grayish red siltite and silty argillite, and contains thin intervals of greenish gray silty argillite, lenticular very thin sandstone, and, locally near the base, very thin limestone beds. Thin sills of diorite, intruded during Late Proterozoic time, are included with the Proterozoic strata.

2. The second rock sequence, of Paleozoic age, is exposed only in thin fault slices beneath the Eldorado thrust fault along the northeast and east edge of the study area. Complete sections of the sequence are likely present at depth beneath the Proterozoic rocks. A complete section of the Paleozoic rocks present southeast of the study area is 4,000-5,425 $\mathrm{ft}$ thick. Discontinuous slices of the Paleozoic sequence beneath the Eldorado thrust fault are generally less than $500 \mathrm{ft}$ thick. The sequence consists of interbedded units of limestone, dolostone, mudstone, siltstone, and sandstone. Carbonate rocks are generally very light gray, whereas terrigenous clastic rocks are greenish gray, dark gray, or grayish red.

3. Interbedded mudstone, sandstone, siltstone, and volcaniclastic sandstone of Mesozoic age comprise the third major rock assemblage of the area. On the northeast margin of the study area, and about Beartooth Mountain in the southeastern part, these rocks support terrain of lower relief than that supported by Proterozoic strata across most of the study area. The Mesozoic strata are repeated by faults that delimit imbricated slices, beneath and east of the major thrust fault that brings the Proterozoic rocks to the surface. The Mesozoic rocks are characteristically dark gray, brownish gray, and locally olive gray to black. Sequences in the upper part include some volcanic welded tuff, basaltic lava, and varicolored volcaniclastic mudstone.

4. Igneous rocks, probably of Late Cretaceous age, intrude strata of the three sequences just described. The rocks range in composition from basic trachybasalt to more siliceous rhyodacite. The intrusive bodies are thin, elongate, and generally parallel bedding and the fabric of older structures. Other bodies are thin sills and dikes. Most seem to have been intruded before thrust faulting, but at least two bodies intrude the major Eldorado thrust fault. In the eastern part of the study area, intensely fractured, brecciated, siltite in the lowermost part of the Eldorado thrust plate is in contact with undeformed rhyodacite; apophyses of rhyodacite intrude the brecciated siltite. All the exposed intrusive rocks are confined to the east and northeast part of the study area, except for a small rhyodacite body that intrudes the Eldorado thrust fault near the northwest corner of the study area (pl. 1).

5. The youngest strata of the Sleeping Giant Wilderness Study Area are veneers of poorly consolidated gravel, sand, and silt on bedrock bars within meanders or on terraces at the edge of the Missouri River, or in channels of intermittent streams that drain the interior of the study area. Very fine grained silt and well-sorted sand, with sparse laminae of diatomite, accumulated in the Missouri River valley when it was flooded by glacial lake Great Falls. Thin deposits of angular bedrock fragments, derived by slopewash and gravity sliding, locally mantle steep slopes within the study area.

The prominent structures in the vicinity of the study area are thrust faults and associated folds that generally trend west-northwest to north-northwest (pl. 1). The thrust faults are part of the Montana disturbed belt, a broad zone of intensely folded and faulted rocks that extends from the Canadian border southward along the eastern front of the Rocky Mountains into the area north of Helena. Along the Eldorado thrust fault, the principal fault within the Sleeping Giant Wilderness Study Area, upper plate Proterozoic rocks were transported across Mesozoic and Paleozoic strata of the lower plate. Both upper and lower plates rocks are allochthonous.

Strata of the lower plate of the Eldorado thrust fault are exposed in the easternmost part of the wilderness study area and in terrain to the north, east, and south (pl. 1). North of the area shown in plate 1 , thrust faults impinge upon autochthonous rocks of the foreland and thrust faults and associated folds dip steeply southwest (Schmidt, 1977). Within the vicinity of the study area and to the east and south, the lower plate is characterized by imbricated faults that dip at low angles to the southwest, and by tight, closely spaced folds that have northwest-trending axes and southwest-dipping axial planes. Each thrust fault of the lower plate in the eastern part of the area flattens westward at depth to join adjacent faults. As the faults merge, the amount of offset on lower faults increases westward beneath the area. Lower plate rocks extend an unknown distance west beneath the Proterozoic rocks, but at least $10 \mathrm{mi}$ west of the study area where the UNOCAL 1-B30 Federal exploration test hole (fig. 1) drilled through upper plate rocks and penetrated Cretaceous, Jurassic, and Paleozoic strata of the lower plate.

The Proterozoic upper plate rocks constitute much of the sequence exposed in the study area and are gently folded or warped about axes that trend west or northwest (Bregman, 1976, 1981). At least locally, the lowermost rocks of the upper plate are intensely brecciated and display small, tight folds; axial planes dip southwest. 
The Eldorado thrust fault dips at a very low angle in the eastern part of the study area. Its sinuous trace reflects this low dip, a scalloped erosional pattern of the Proterozoic rocks of the upper plate, and the warping (folding) that may have occurred after emplacement of the upper plate. Within the upper plate, subsidiary thrust faults of the Eldorado fault have small displacements that offset and repeat the Proterozoic rocks. Rocks of the upper plate have been transported at least $20 \mathrm{mi}$ east-northeast. This determination reflects regionally extensive structural studies that take into account ongoing mapping of author Reynolds in the Big Belt Mountains east and southeast of the study area. Bregman (1981) previously had calculated a minimum displacement of $10.5 \mathrm{mi}$ based on more localized parameters.

A cross section showing strata of and beneath the Eldorado plate is illustrated on plate 1. The section is based on mapping during the course of this study, on mapping of Bregman (1981), on mapping of Robinson and McCallum (1991), and, beneath the Eldorado thrust fault, on projection of strata and structures mapped to the south by Robinson and others (1969) and to the north by Schmidt $(1972,1977)$.

The base of steep hillsides along the southwestern margin of the study area marks the trace of the westnorthwest-trending, high-angle Hilger Valley fault, a normal fault along which Hilger Valley was dropped at least $3,500 \mathrm{ft}$ with respect to the mountains of the study area. Directly north of Hilger Valley, flanking hillslopes of Proterozoic rocks are offset progressively down toward the valley. The fault is concealed within the study area, but to the southeast in Hilger Valley, south of the area shown in plate 1, middle Tertiary strata exposed in the valley are downdropped along the high-angle Hilger Valley fault. The fault is youthful and marks the northern limit of a zone of faults several miles wide that define the Lewis and Clark "line" (Billingsley and Locke, 1939). The line is a major northwest-trending discontinuity in the crust that has been active recurrently since Proterozoic time and, in the Cenozoic, along which west-central and southwestern Montana has broken and extended west relative to the northwestern part of the State (Reynolds, 1979).

\section{Geochemistry}

\section{Analytical Methods}

Geochemical data for this study were obtained from stream-sediment, heavy-mineral (panned) concentrate, and rock samples collected during the summer of 1987. The analytical data for the stream-sediment and heavy-mineral concentrate samples, as well as a description of the stream sampling and analytical techniques used, are given in Malcolm and Carlson (1990). The analytical data for the rock samples are given in the present report. Sample localities for all analytical data are shown on plate 1 .
Stream sediments and panned concentrates were collected at 58 localities (sites) in and adjacent to the study area and were subsequently prepared and analyzed as minus-80-mesh sediments and as nonmagnetic and paramagnetic heavy-mineral concentrates, respectively. These sample media represent a composite of rock and soil materials exposed in the drainage basin upstream of each sample site. The minus- 80 -mesh sediment gives the general chemical signature of the basin, with some enhancement of elements that tend to adsorb on clay minerals. The heavymineral concentrates enhance certain elements that may indicate anomalous mineralization in the drainage basin. The stream samples were collected from first-, second-, and third-order streams and represent a density of 1 sample per $0.5 \mathrm{mi}^{2}$ (square miles).

The minus-80-mesh sediments were analyzed for 35 elements by a semiquantitative emission spectrographic method (Grimes and Marranzino, 1968) and for 5 elements by a wet chemical method (Crock and others, 1987). The nonmagnetic and paramagnetic fractions of the heavymineral concentrates were analyzed for 37 elements by the semiquantitative emission spectrographic method of Grimes and Marranzino. In addition, mineralogical splits of the concentrates were examined for visible evidence of mineralization and contamination from human activities in the area.

Rock samples were collected from 39 localities and analyzed to provide the background chemistry of geologic units in the study area as well as the chemistry associated with sheared, veined, altered, and mineralized rocks found during geological mapping traverses. The rock samples were crushed and ground by ceramic plates to less than 100 mesh size and analyzed for 35 elements by the method of Grimes and Marranzino (1968), for 5 elements by the method of Crock and others (1987), and for gold by the wet chemical method of O'Leary and Meier (1984). The analytical data for the rock samples are presented in table 3 .

\section{Results of Study}

The analytical data show anomalous concentrations of lead, zinc, tin, antimony, copper, and silver, compared with the background levels for these elements in the study area. Based on microscopic study of the mineralogical splits and association of the anomalies with areas of high access, lead, zinc, tin, and antimony were determined to have originated as contamination from human endeavors.

Anomalous lead values ranged from 700 to 20,000 ppm in the nonmagnetic heavy-mineral concentrates (pl. 1, localities 4S, 9S, 10S, 11S, 12S, 13S, 14S, 16S, 17S, 21S, $22 \mathrm{~S}, 39 \mathrm{~S}, 42 \mathrm{~S}, 47 \mathrm{~S}$, and 54S) compared with an area background ranging from undetected (detection limit of 20 ppm) to $500 \mathrm{ppm}$ and averaging $90 \mathrm{ppm}$. Lead chips, shavings, and other presumed bullet fragments were observed in the mineralogical splits of samples showing 
values of 1,500 ppm and higher, and anomalous values of 700 to $1,000 \mathrm{ppm}$ in samples were closely associated with roads and hunting camps, possibly indicating contamination by humans.

Randomly arranged anomalous values for zinc of $500-5,000 \mathrm{ppm}$ in the nonmagnetic heavy-mineral concentrates (pl. 1, localities 9S, 10S, 12S, 18S, 32S, 33S, $36 \mathrm{~S}, 47 \mathrm{~S}$, and 50S) compare with an area background of undetected (detection limit of $500 \mathrm{ppm}$ ). The anomalies probably are due to contamination by human activities, as indicated by the apparent lack of correspondence between the anomalies and areal or geologic control, the general association with areas of human disturbance, and one microscopically observed flake of zinc metal plating.

Anomalous tin values of $1,000-3,000 \mathrm{ppm}$ in the nonmagnetic heavy-mineral concentrates compare with an area background range of undetected (detection limit of 20 $\mathrm{ppm}$ ) to $500 \mathrm{ppm}$. The anomalous sites (pl. 1, localities $12 \mathrm{~S}$, 13S, 17S, 21S, and 22S) show some areal and geologic correspondence with drainage basins adjacent to each other in the Greyson and Spokane Formations of the same thrust plate. However, examination of the mineralogical splits showed no microscopically visible cassiterite (even after sonic cleaning of the grains) and no molybdenite, fluorite, or topaz commonly associated with tin minerals. In addition, the diffractogram from X-ray analysis of the analyzed samples showed no patterns for these minerals. The probable source for the anomalous tin values is microscopic metal shavings that were observed in the sample; the shavings were produced by humans.

The area background for antimony in the nonmagnetic heavy-mineral concentrates is at or below the detection limit of $200 \mathrm{ppm}$. One lone anomaly of $1,500 \mathrm{ppm}$ at locality $17 \mathrm{~S}$ (pl. 1) was not attributable to any natural mineral source and is considered to be human contamination, possibly as a hardening agent for the lead alloy microscopically visible in that sample.

Copper and silver are the other two metal elements that occur in anomalous concentrations in and adjacent to the study area. Although their anomalies appear related to natural mineralization, the concentrations are too low to indicate any significant economic potential.

Anomalous copper values of $200-1,000 \mathrm{ppm}$ in the nonmagnetic heavy-mineral concentrates (pl. 1, localities $10 \mathrm{~S}, 11 \mathrm{~S}, 12 \mathrm{~S}$, and 13S) compare with an area background ranging from 7 to $200 \mathrm{ppm}$ and averaging $55 \mathrm{ppm}$. The source for the anomalous copper concentrations appears to be scattered occurrences in the siltites of the Spokane Formation; minor malachite was observed in siltites near sample localities $35 \mathrm{R}$ and $36 \mathrm{R}$ (pl. 1) and the siltite of locality $32 \mathrm{R}$ (pl. 1) had a copper value of $2,000 \mathrm{ppm}$ (table 3).

The background for silver values in the study area is below the 1-ppm detection limit for rocks and minus80-mesh stream-sediment samples and below the 0.5-ppm detection limit for nonmagnetic and paramagnetic fractions of the heavy-mineral concentrates. "Anomalous" values of silver for these four sample media are at, or slightly above, their detection limits and possibly represent the upper end of the background range for silver in these media as related to the geologic units involved. Values ranging from 0.7 to 1.5 $\mathrm{ppm}$ in the nonmagnetic heavy-mineral concentrates (pl. 1, localities $12 \mathrm{~S}, 14 \mathrm{~S}$, and $17 \mathrm{~S}$ ) probably are related to silver in the Spokane Formation as seen in siltites at sites 32R (5 ppm silver) and 26R (0.7 ppm silver) (pl. 1, table 3). Values of 1-3 ppm silver in the same sample medium for localities 29S, 31S, and 54S (pl. 1) may relate to the rhyodacite of Beartooth Mountain, although no silver was detected in samples $13 \mathrm{R}$ and $29 \mathrm{R}$ (pl. 1). Values ranging from 1 to 5 $\mathrm{ppm}$ in the paramagnetic fraction of the heavy-mineral concentrates of samples $14 \mathrm{~S}, 30 \mathrm{~S}, 37 \mathrm{~S}, 38 \mathrm{~S}$, and $41 \mathrm{~S}$ (pl. 1) may represent hematitic adsorptions of silver from the same two sources. Silver values of 0.5 and $0.7 \mathrm{ppm}$ in the minus-80-mesh stream sediments of localities $8 \mathrm{~S}, 35 \mathrm{~S}, 50 \mathrm{~S}$, 51S, 52S, and 53S (pl. 1) probably represent adsorptions of mobilized silver on clay minerals. The source of the silver is unknown, but could be an eroded low-level silver source such as the Spokane Formation.

\section{Landsat Imagery}

\section{Methods}

Digital analysis of Landsat Multispectral Scanner (MSS) images have been used for more than a decade to analyze hydrothermally altered rocks (Rowan and others, 1974). Ferric-oxide and hydrous-oxide minerals, collectively termed limonite, absorb electromagnetic radiation intensity in the MSS response range (fig. 3). By combining selected ratios of MSS channels, color-ratio composite images of areas of anomalously high limonite concentrations can be displayed in a specified image color. Anomalously limonitic rocks are delineated on the colorratio composite image or plotted directly using the appropriate digital number (DN) ranges. Extensive field evaluation is needed for distinguishing the limonitic hydrothermally altered rocks from limonitic-weathering unaltered rocks. In addition, nonlimonitic hydrothermally altered rocks cannot be detected using color-ratio composite MSS images (Rowan and others, 1977).

Landsat Thematic Mapper (TM) images, used to examine rocks of the Sleeping Giant Wilderness Study Area, differ from MSS images in having additional spectral channels in the near-infrared wavelength region (fig. 3) and higher spatial resolution ( $30 \mathrm{~m}$ versus $79 \mathrm{~m}$ ). Most hydrothermally altered rocks contain $\mathrm{OH}$-bearing minerals, such as kaolinite, alunite, pyrophyllite, K-mica, and montmorillonite. Molecular vibrations in these minerals cause $\mathrm{OH}-$ absorption features that can be detected in the TM images. 


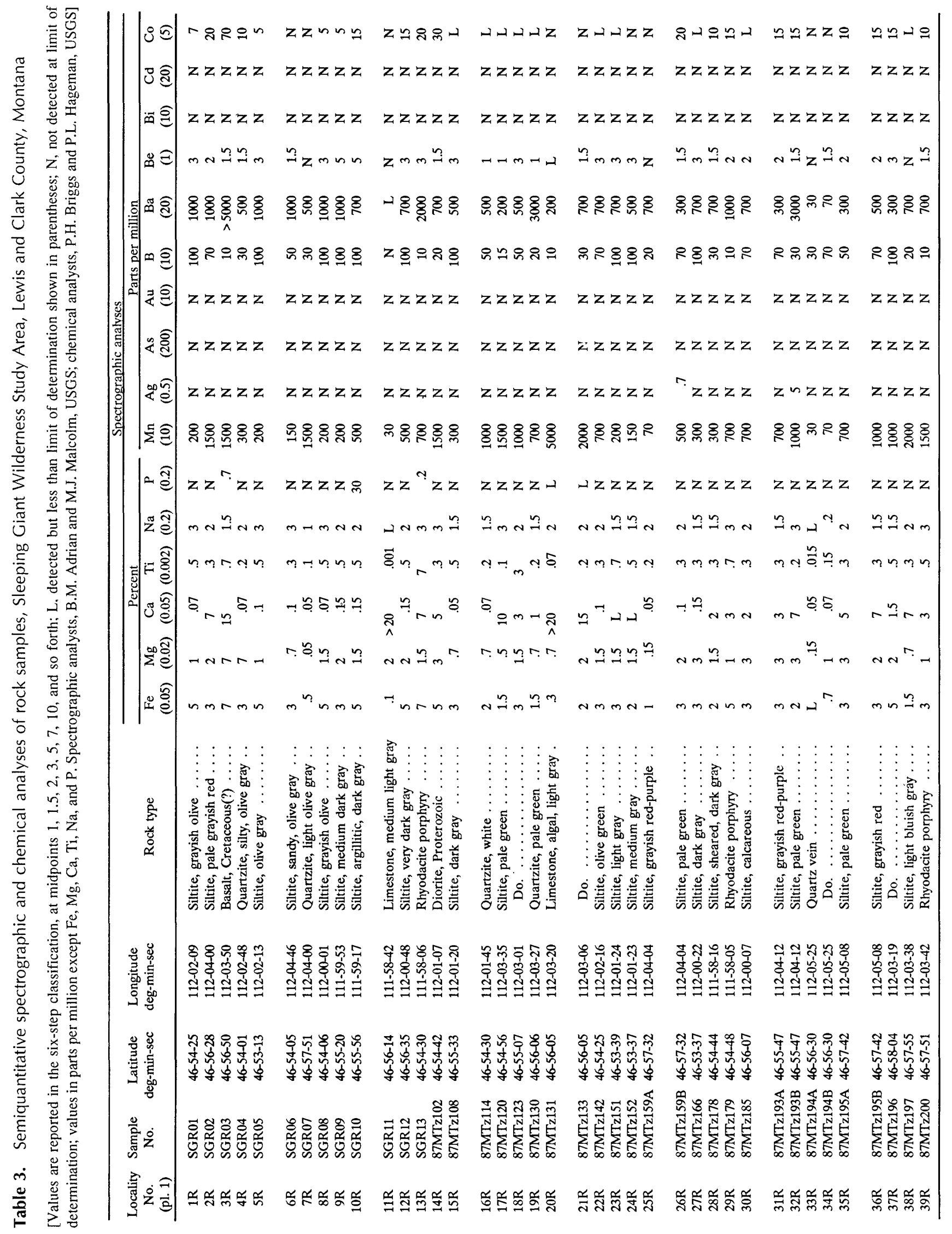




\begin{tabular}{|c|c|c|c|c|c|c|c|c|c|}
\hline \multirow{6}{*}{ | } & $\mid \begin{array}{l}\bar{\varepsilon} \\
\dot{e}\end{array}$ & カルヘルカ & ヘルヘルロ & ムムルヘム゙ & 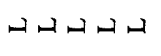 & 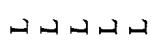 & ヘルルルル & カルヘカル & ヘルルカ \\
\hline & ง $\widehat{c}$ & 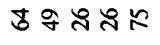 & $2 \approx n \delta 8$ & 숭 생 夺 & 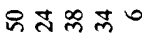 & ษก๊ก๊ & 역으요 & ర్ర익 & 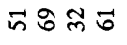 \\
\hline & 83 & ムムムムム & ユルルルル & ルルルルル & ヘルルへツ & 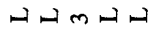 & カコムヘル & ルムムルロ & ルルルコ \\
\hline & $\tau$ & 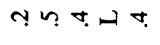 & ત૫ ૫ ૧ ભ ૫ & મナナ. & 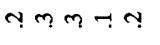 & ஊッヘルニ & 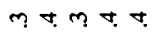 & 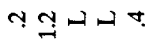 & ૪ ォ ๆ \\
\hline & in & ユム & ユムムムム & カコルヘル & ユルへコル & ユムムムム & カへヘへル & カコルルカ & ヘルコル \\
\hline & $\&$ & のルルルの & 0, & 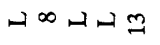 & ヘルムニル & - & \lrcorner$\infty$ ๑ & ルルルルコ & ルルのル \\
\hline & & $\mathbf{z} \mathbf{z} \mathbf{z} \mathbf{z} \mathbf{z}$ & $\mathbf{z} \mathbf{z} \mathbf{z} \mathbf{z} \mathbf{z}$ & $\mathbf{z} \mathbf{z} \mathbf{z} \mathbf{z} \mathbf{z}$ & $\mathbf{z} \mathbf{z} \mathbf{z} \mathbf{z} \mathbf{z}$ & $\mathbf{z} \mathbf{z} \mathbf{z} \mathbf{z} \mathbf{z}$ & z z z z z & $\mathbf{z} \mathbf{z} \mathbf{z} \mathbf{z} \mathbf{z}$ & $z z z z$ \\
\hline & & $\mathbf{z} \mathbf{z} \mathbf{z} \mathbf{z} \mathbf{z}$ & $z z z z z$ & $\mathbf{z} \mathbf{z} \mathbf{z} \mathbf{z} \mathbf{z}$ & $\mathbf{z} \mathbf{z} \mathbf{z} \mathbf{z} \mathbf{z}$ & $z \mathbf{z} z \mathbf{z} \mathbf{z}$ & $\mathbf{z} \mathbf{z} \mathbf{z} \mathbf{z} \mathbf{z}$ & $z z z z z$ & $z z z z$ \\
\hline & & ర유뮤. & శి. & Z 유요 ని & 음동 & లిలిని ニ & 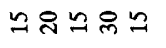 & 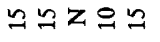 & 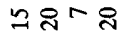 \\
\hline & & 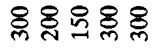 & 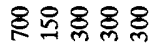 & Z శ్రి శ్లిన శ్లి & 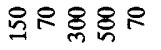 & 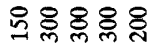 & 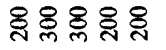 & 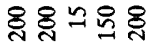 & 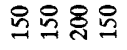 \\
\hline & & $\mathbf{z} \mathbf{z} \mathbf{z} \mathbf{z} \mathbf{z}$ & Z Z Z Z Z & ZZZZZ Z & z z z z z z & $z z z z z$ & z z z z z & $z z z z z$ & $\mathbf{z} \mathbf{z} \mathbf{z} \mathbf{z}$ \\
\hline & & 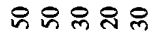 & 尺ㅠำ & 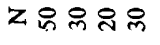 & 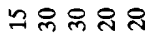 & 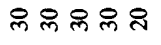 & 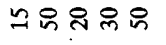 & 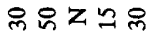 & ర్లిర్లి ర్ల \\
\hline & 3 & z Z Z Z Z Z & $z z z z z$ & $z z z z z$ & z z z z z & z z z z z & Z Z Z Z Z Z & $z z z z z$ & z Z Z Z \\
\hline & & 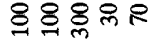 & 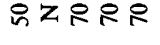 & 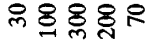 & 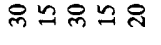 & ท゚R゚R กิ & 요욤요요 & 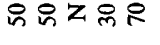 & คะ유 \\
\hline & & 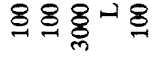 & 익욤욤 & 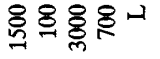 & 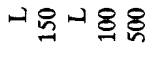 & 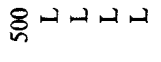 & এএ음 & ルルスZル & এスッ呑 \\
\hline & 5 & $z z z z z$ & $z z z z z$ & $z \mathbf{z} z \mathbf{z} \mathbf{z}$ & $\mathbf{z} \mathbf{z} \mathbf{z} \mathbf{z} \mathbf{z}$ & $z z z z z$ & $\mathbf{Z} \mathbf{Z} \mathbf{Z} \mathbf{Z} \mathbf{Z}$ & $z z z z z$ & $\mathbf{Z Z Z Z}$ \\
\hline 豆 & & $\because \simeq 8$ & 으늑 & Zこニ恕 & nntan & 오오그옴 & $r$ 음 & ng的 & $\approx \cong-n$ \\
\hline & & Z Z Z Z Z & $\mathbf{z} \mathbf{z} \mathbf{z} \mathbf{z} \mathbf{z}$ & $\mathbf{z} \mathbf{Z} \mathbf{z} \mathbf{z} \mathbf{z}$ & z Z Z Z z & $z z z z z$ & z Z Z z z Z & z z z z z & $z z z z$ \\
\hline & & 이용ㅇㅇㅇㅛ & 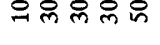 & 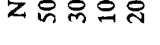 & ニニ요 & ని ニ నిల్లె & ్ㅠ유즈으 & 용 z z n & カேะ゚ \\
\hline & & 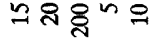 & ル유 ニ & Z శ్నా - లి & 워ールル & 용요 & ్ㅠニ 온 & శి శి Zル & 쥬유-1 \\
\hline & & ルヘ8્⿹弋 & ヘルヘルル & カカヘヘカ & ルルムル Z & Zムルルム & ヘルヘルの & ルルルルさ & ヘルヘ川 \\
\hline & & $\mathbf{z} \mathbf{z} \mathbf{z} \mathbf{z} \mathbf{z}$ & $z z z z z$ & $\mathbf{z} \mathbf{z} \mathbf{z} \mathbf{z} \mathbf{z}$ & $\mathbf{z} \mathbf{z} \mathbf{z} \mathbf{z} \mathbf{z}$ & $z z z$ in $z$ & z z z z z & $z \sim z z z$ & $z z \sim z$ \\
\hline & & zに马 & 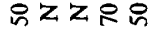 & そ゚マロル & 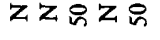 & 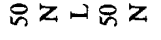 & 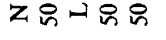 & $z$ z & ヘミ゚ー \\
\hline & & ณ์・น & ำニ요 & এㅇㅛㅛㅛ & 9ルロルッ & ๓ュュே & ルニュア゚ュ & 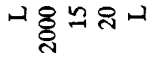 & ルヘ8્ત્ત \\
\hline & & 유욤요 요 & ల్లుర్లిర్లి & 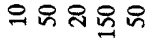 & ని ニ లిలి జి & దํㅠㅠㅈㅜ & సిల్లిగిల్లి & 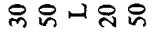 & 요믐 \\
\hline $\begin{array}{l}\text { త్ర్ } \\
\end{array}$ & $i^{\circ}$ & 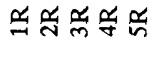 & 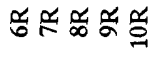 & 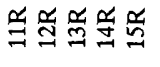 & 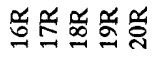 & 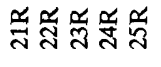 & 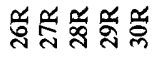 & 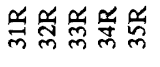 & 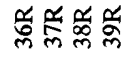 \\
\hline
\end{tabular}




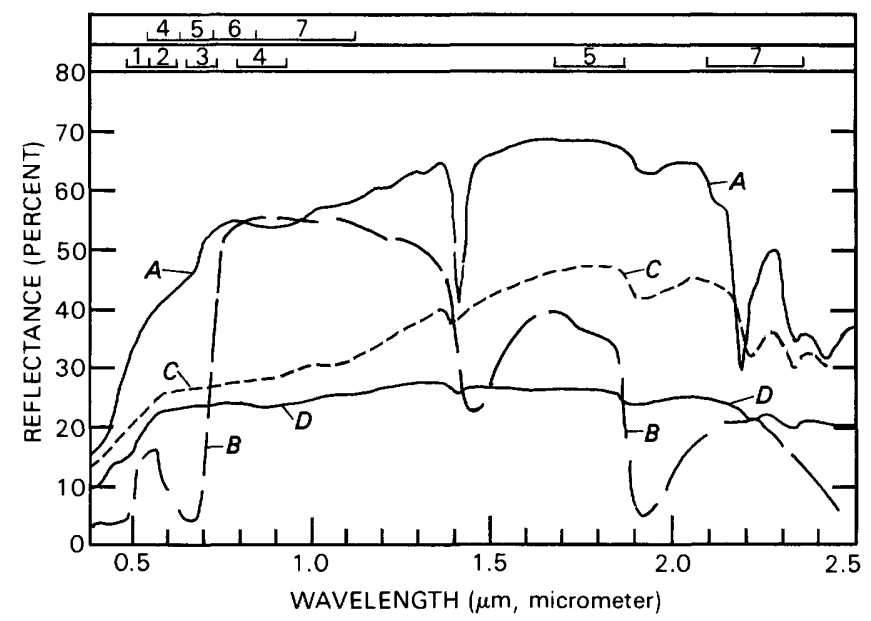

Figure 3. Diagram showing reflectance spectra of limonitic rock. A, Limonitic muscovite-bearing hydrothermally altered rock showing $\mathrm{Al}-\mathrm{OH}$ absorption feature at $2.20 \mu \mathrm{m}$ (one millionth of a meter), and $\mathrm{Fe}^{3+}$ absorption features near 0.90 $\mu \mathrm{m}$ and shorter wavelengths; $B$, pine tree exhibiting chlorophyll absorption at $0.68 \mu \mathrm{m}$, high $0.7-1.2 \mu \mathrm{m}$ reflectance and $\mathrm{HOH}$ absorption at $1.4 \mu \mathrm{m}, 1.9 \mu \mathrm{m}$ and longer wavelengths; $C$, green siltite; and $D$, red siltite from Sleeping Giant Wilderness Study Area, Montana. At top, Landsat Multispectral Scanner (MSS) channels on top line and Thematic Mapper (TM) channels on lower line.

Therefore, bleached, nonlimonitic as well as limonitic hydrothermally altered rocks can be mapped in TM images. However, field evaluation is still necessary because some of these minerals are also common in unaltered rocks.

For the study area, the appropriate part of TM scene number 50546-1748 (recorded on August 29, 1985) was digitally processed. The TM3/TM1 ratio was used to identify pixels that have high $\mathrm{Fe}^{3+}$ absorption, and the TM5/TM7 ratio was used to identify the high $\mathrm{OH}-$ absorption pixels. Because vegetation also has moderately high TM5/TM7 ratios, owing to water absorption (Knipling, 1969), the TM4/TM3 ratio was used to identify pixels representing vegetation. A color composite image was made using the following $\mathrm{TM}$ ratio and color assignment: TM5/TM7 = red, TM3/TM1 = green, and TM4/TM3 = blue . In this color-ratio composite image, limonitic rocks appear green, OH-bearing rocks appear red, and rocks containing both appear yellow. Yellow areas were delineated in the color-ratio composite image and are outlined on plate 1 .

\section{Interpretation of Imagery}

The areas shown on plate 1 , examined in the field during August, 1987, contain green to yellow-brown siltite and red siltite of the Middle Proterozoic Greyson and Spokane Formations. No hydrothermally altered rocks were found. OH-bearing minerals in the siltites caused moderately high TM5/TM7 ratio values, whereas iron absorption caused high, TM3/TM1 ratios.
Visible and near-infrared $(0.4-2.5 \mu \mathrm{m})(1 \mu \mathrm{m}=$ one millionth of a meter) reflectance spectra of samples from these areas were recorded in the laboratory. Spectra that represent the green and red siltites are shown in figure 3. Spectrum C, representing the green siltite, is characterized by sharp absorption features centered near $2.20 \mu \mathrm{m}$ and 2.35 $\mu \mathrm{m}$ and broad absorption features near $0.70 \mu \mathrm{m}, 0.90 \mu \mathrm{m}$, and $1.10 \mu \mathrm{m}$. The $2.20-\mu \mathrm{m}$ feature is attributed to $\mathrm{Al}-\mathrm{OH}$ absorption probably in $\mathrm{K}$-mica, although clay minerals caused by weathering may also contribute to this absorption feature. The $2.35-\mu \mathrm{m}$ absorption feature probably is related to $\mathrm{Mg}-\mathrm{OH}$ absorption in chlorite. These $\mathrm{OH}$-absorption features cause low reflectance in TM7 and, therefore, the high TM5/TM7 ratio observed in the color-ratio composite image.

The $0.90-\mu \mathrm{m}$ feature is caused by electronic transitions in $\mathrm{Fe}^{3+}$, whereas the $0.70-\mu \mathrm{m}$ and $1.10-\mu \mathrm{m}$ bands are related to $\mathrm{Fe}^{2+}$ absorption, probably in chlorite. The absorption features near $1.4 \mu \mathrm{m}$ and $1.9 \mu \mathrm{m}$ are due to water, but TM does not record data in the regions of strong atmospheric absorption.

The red siltite is represented by laboratory reflectance spectrum $\mathrm{D}$ in figure 3 . Weak $\mathrm{Al}-\mathrm{OH}$ and $\mathrm{Mg}-\mathrm{OH}$ features are present near $2.20 \mu \mathrm{m}$ and $2.35 \mu \mathrm{m}$, respectively, probably due to K-mica and chlorite, respectively, of spectrum $\mathrm{C}$. The broad absorption feature near $0.90 \mu \mathrm{m}$ and the rapid decrease in reflectance towards wavelengths shorter than $0.60 \mu \mathrm{m}$ are typical of $\mathrm{Fe}^{3+}$ absorption. Although the TM5/TM7 ratio for this spectrum is substantially lower than for spectrum C (fig. 3), the imageprocessing procedure resulted in its red expression in the color-ratio composite image.

\section{Geophysics}

\section{Methods}

The Sleeping Giant Wilderness Study Area is covered by reconnaissance aeromagnetic and gravity surveys that were designed in support of mineral resource evaluations and regional framework investigations of the Montana disturbed belt. Variations in gravity and magnetic field intensities are reduced to anomaly maps for use in interpretation of geology and the mineral resource potential (figs. 4 and 5).

The contoured Bouguer gravity anomaly map (fig. 4) is based on observations at 90 gravity stations, 20 of which lie within the boundaries of the study area. Most of the 20 stations were established during the course of our study, using a four-wheel-drive vehicle and a helicopter. The magnetic anomaly data (fig. 5) are derived from two aerial surveys, which include the southeast and northwest parts of the map area (Kleinkopf and Mudge, 1972; U.S. Geological Survey, 1979). The western half of the study area also is 
covered by an additional magnetic survey (U.S. Geological Survey, 1984), which was not used for interpretation here because of its wide spacing of flight lines. Measurements for both surveys record the magnitude of total magnetic field of the earth along flight traverses oriented northeastsouthwest. The northwest part was flown at a barometric elevation of $7,000 \mathrm{ft}$ above sea level and the southeast part was flown at $9,000 \mathrm{ft}$ above sea level with line spacings of 1 and $2 \mathrm{mi}$, respectively.

The gravity and magnetic anomaly patterns reflect contrasts in the density and magnetization of the rocks. In our study of the wilderness area, rocks exposed at the surface are assumed to be representative of rocks present in the subsurface. The geophysical data are interpreted in keeping with the geophysical properties of the five generalized rock sequences described in a previous section of this report. The oldest sequence, the Middle Proterozoic Belt Supergroup, comprises mainly argillite, siltite, and sandstone. These rocks are regionally metamorphosed and typically are nonmagnetic, but they are the most dense of the five sequences; we estimate their density to be more than $2.70 \mathrm{~g} / \mathrm{cm}^{3}$ (gram per cubic centimeter). Thin sills of diorite within the Belt Supergroup make up only a small percentage of the rock volume. The Paleozoic sequence, which consists of carbonate and clastic rocks that are assumed to underlie the study area, is nonmagnetic and has estimated densities of $2.67-2.70 \mathrm{~g} / \mathrm{cm}^{3}$. The third rock sequence is of Mesozoic age and consists of mudstone, sandstone, siltstone, and volcanic and volcaniclastic rocks. This suite of rocks is also nonmagnetic; densities are estimated to average about $2.65 \mathrm{~g} / \mathrm{cm}^{3}$. Late Cretaceous igneous rocks, the fourth sequence in the study area, ranges in composition from trachybasalt to rhyodacite, for example the Two Medicine Formation. Outside the boundary of the study area, in the northeast and northwest quadrants of the map area (fig. 4), high magnetic gradients correlate with the volcanic rocks and thick mafic sills. Within the study area, exposures of the igneous rocks are limited to the east and northeast margins; steep gradients are lacking because of the apparent small volume of these rocks, even though some of them are magnetic. The youngest rock sequence in the study area comprises sediments, unconsolidated rock materials of alluvial deposits in the lower elevations, and veneers of debris that mantle slopes at higher elevations. These thin deposits exhibit no magnetic or gravitational expression.

\section{Interpretation of Geophysics}

The Sleeping Giant Wilderness Study Area is located at the convergence of northwest and east-west regional gravity and magnetic trends, which can be observed in figures 4 and 5 and in small-scale maps of Kleinkopf and Mudge (1972). These regional trends reflect features of the northwesterly trending Montana disturbed belt and probable deep-seated, east-west oriented structures in the crust.
On the average, the Bouguer gravity field dips at a rate of nearly one mGal (milligal) per mile in a southwesterly direction across the map area (fig. 4). Gravity values, expressed in increments of 2 -mGal contours, decrease from $-144 \mathrm{mGal}$ in the northeast part of the map area to $-154 \mathrm{mGal}$ in the southwest, which is part of the complex regional gravity gradient associated with this part of the Montana disturbed belt. The study area is situated over an anomalous east-west terracing of the regional gradient. The terrace is defined by a marked westerly deflection of the $-148 \mathrm{mGal}$ contour for a distance of about $5 \mathrm{mi}$ to the western end of the study area (fig. 4). The highest gravity values form a positive anomaly at the western boundary of the study area and probably reflect north and northwest structure either in or beneath highdensity rocks of the Belt Supergroup in the upper plate of the Eldorado thrust fault. The gentle increase of gravity values in a westerly direction across the map area, and beyond, suggests a possible gradual thickening, probably in an undulating fashion, of the high-density rocks of the Eldorado thrust plate. These strata are interpreted to be about $10,000 \mathrm{ft}$ thick in the western part of the study area (pl. 1, cross section). About $10 \mathrm{mi}$ west of the study area (fig. 1), the recently abandoned UNOCAL 1-B30 Federal petroleum exploration borehole penetrated about $12,200 \mathrm{ft}$ of Proterozoic rocks above the Eldorado thrust fault.

The magnetic anomaly field decreases gently southsouthwest across the map area (fig. 5) and, similar to the gravity, shows a broad, but complex terracing beneath the study area. In the western part of the study area, converging magnetic trends reflect intersecting regional structural trends, probably formed in Mesozoic rocks beneath the Eldorado thrust fault. This part of the study area may have been favorable for emplacement of igneous intrusions not detected in the regional magnetic anomaly data. Near the eastern boundary of the study area, broad gravity and magnetic lows correlate with imbricate thrust faults east of the Eldorado thrust fault. Arcuate patterns in the geophysical contours of the western survey conform roughly to the arcuate shape of the leading edge of the Eldorado thrust plate and to the arcuate shape of imbricate thrust sheets that contain magnetic and high density rocks of the Two Medicine Formation, which probably accounts for the geophysical patterns. In the west-central part of the study area, a northwesterly trending positive magnetic anomaly, and just to its north a southwesterly trending negative anomaly, may result from structures beneath the Eldorado thrust plate. Alternatively, the positive and negative anomalies may be a dipole pair above a deeply buried granitic intrusive stock. These anomalies occur at the southern edge of the northwest magnetic survey (fig. 5) and the full extent of the anomalies is not observed. The lower resolution survey to the southeast does not show the anomalies. 


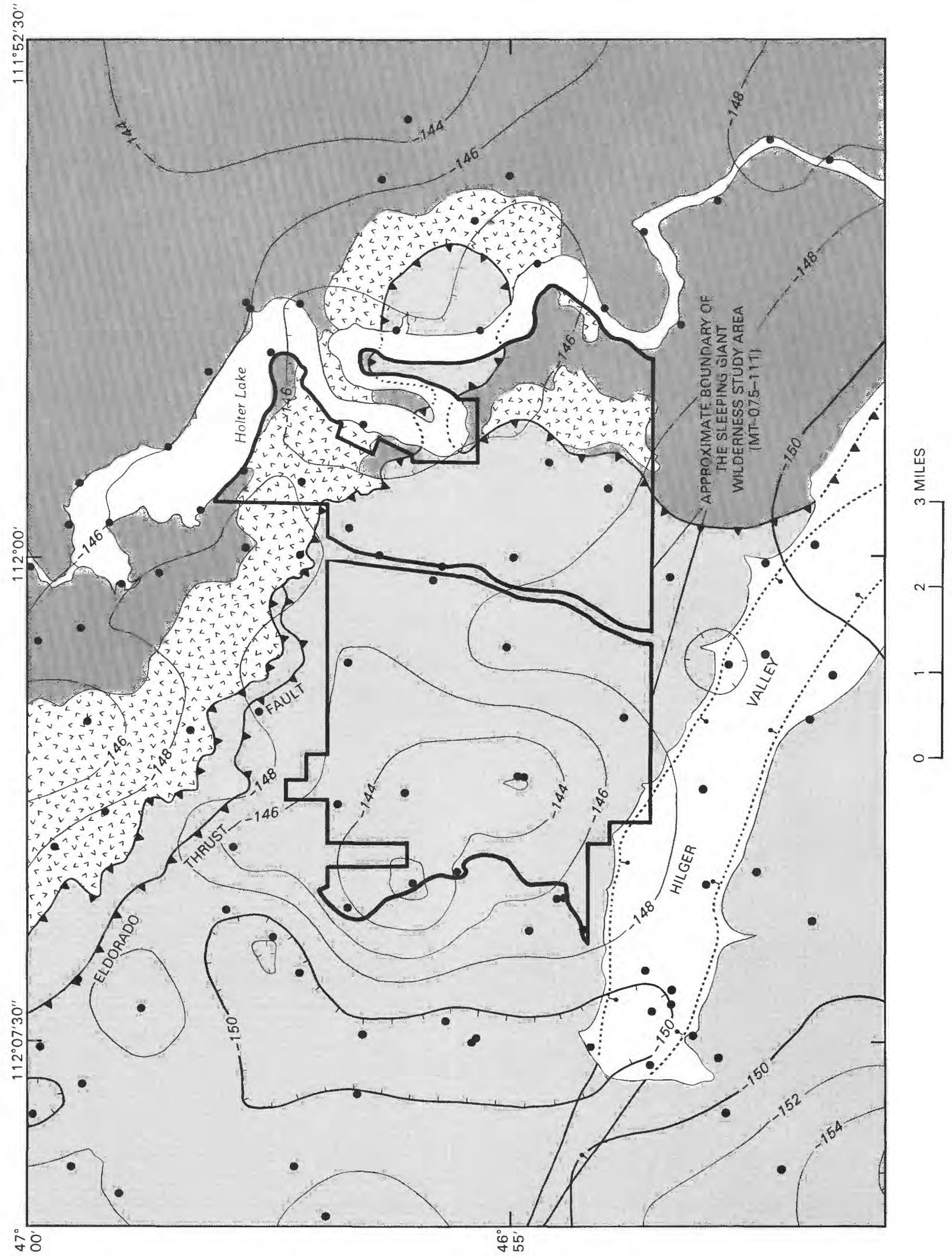




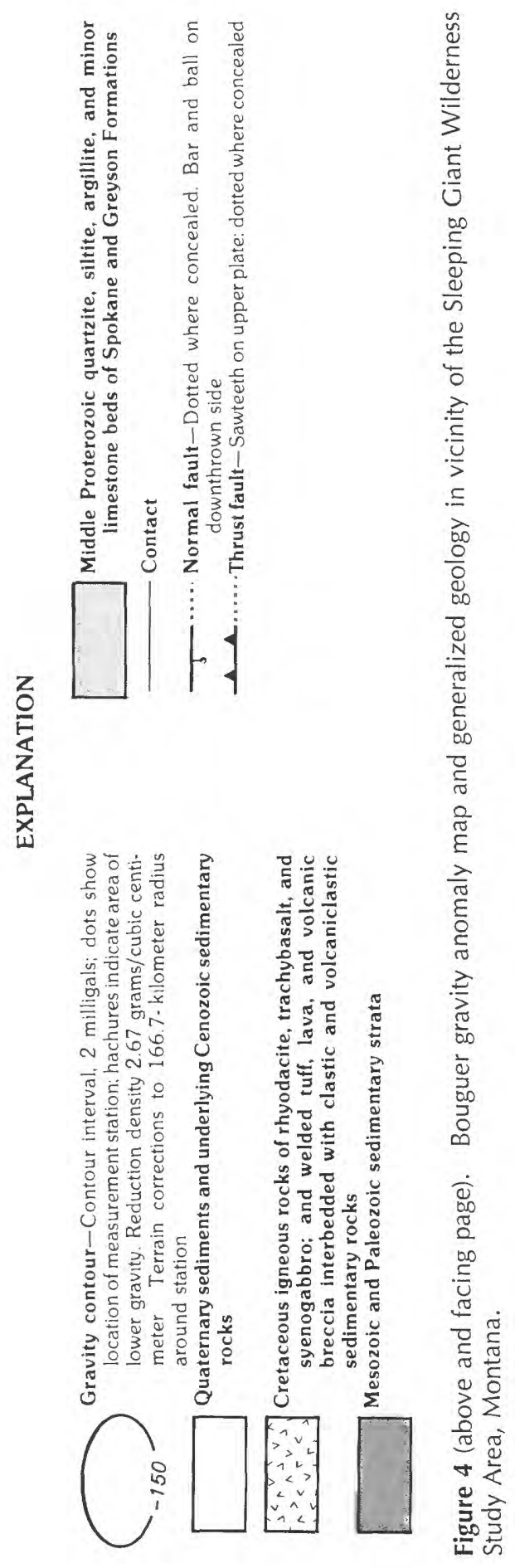

The magnetic and gravity anomaly data of the study area show no solid evidence for granitic intrusions of the type that have associated mineral deposits $20 \mathrm{mi}$ westsouthwest of the study area (where the Granite Peak and Silver Bell stocks occur; Kleinkopf and Mudge, 1972). An area permissible for a fairly nonmagnetic buried igneous intrusion, in addition to the dipole(?) anomaly mentioned, is in the northwest quadrant of the study area where a magnetic saddle correlates with the central part of the broad gravity high. However, no surface geologic evidence was found to suggest a buried intrusive body.

\section{Mineral Resource Potential}

\section{Strata-bound Copper-Silver Deposits}

Strata-bound copper- and silver-sulfide minerals occur in siltite and limestone of the Spokane Formation of the Belt Supergroup in and adjacent to the western part of the study area. Copper- and silver-sulfide minerals in strata-bound deposits occur in three types of rocks in the Belt Supergroup of western Montana: (1) quartzite (metamorphosed sandstone); (2) green siltite (metamorphosed siltstone) and argillite (metamorphosed mudstone), referred to collectively as green beds; and (3) carbonate (limestone and dolostone) beds (Harrison, 1972, 1974; Harrison and others, 1986; Lange and Sherry, 1986). Ore minerals in the quartzite-hosted (sandstone-hosted) sulfide deposits are concentrated in white, buff, gray, or pale-green fine- to medium-grained quartzite units that are commonly several tens of feet thick, locally crossbedded, and possibly related to steeply dipping faults (Clark, 1971; Harrison, 1974; Harrison and others, 1986; Lange and Sherry, 1986; Hayes and Einaudi, 1987). Potential host rocks for quartzite deposits are limited in the study area, although Peters and Winters (1988) believe the deposit at locality no. 4 is quartzite-hosted. The quartzite deposit type is not considered specifically in the following discussion, but the general model characteristics presented here apply to the deposit type.

Mineralized green beds are present in nearly all formations of the Belt Supergroup in western Montana (Harrison, 1972, 1974), but carbonate-host rocks are known only in the Helena or Wallace Formations (Harrison, 1972, 1974) and in limestone to calcareous siltstone of the Spokane Formation (Lange and Eby, 1981; Lange and Sherry, 1986; Lange and others, 1987). The Helena or Wallace Formations are not present in the vicinity of the study area, but the Spokane Formation crops out in and adjacent to the western part of the study area and contains both green bed- and carbonate-hosted mineralized rock. Both the green bed- and carbonate-hosted rocks occur within a sequence of red beds composed of metamorphosed sandstone, siltstone, and mudstone. 


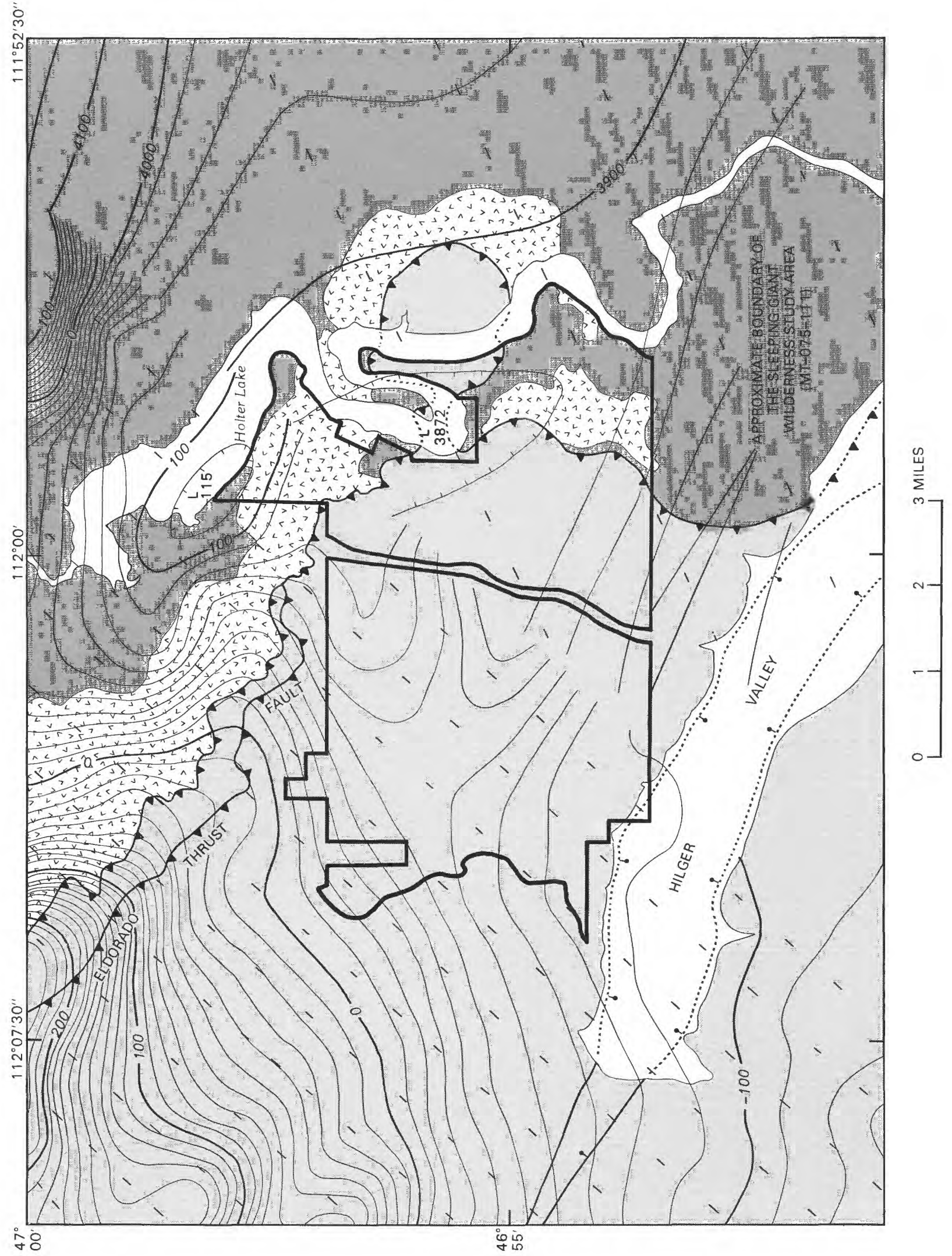


Characteristics of copper-bearing strata-bound deposits and mineral occurrences found worldwide have been summarized in a review article by Gustafson and Williams (1981). General characteristics (numbered characteristics that follow) comprise the framework for a deposit model. Data concerning mineral occurrences in green beds and carbonate rocks, the most likely host strata in the study area, are presented for each of the general characteristics. Data specific to green-bed host rocks are mainly from Harrison and Reynolds (1979) who examined mineralized drill core from the upper part of the Spokane Formation at Blacktail Mountain near Kalispell, Montana (fig. 1). The site was drilled by the USGS in an attempt to develop a model for green-bed copper-silver occurrences in rocks of the Middle Proterozoic Belt Supergroup. Data specific to mineralized carbonate rocks, which also are associated with green beds, are mainly from Lange and Sherry (1986), Lange and others (1987), and Peters and Winters (1988). They examined strata in the lower part of the Spokane Formation along Interstate Highway 15 directly west of the study area (fig. 1 and pl. 1).

1. Mineralized strata-bound rocks were deposited within a few feet of an aquifer that carried the mineralizing solutions. The aquifer may have become impermeable after diagenesis of the sediments. In western Montana, permeability controlled the distribution of copper-silver sulfide minerals in both green beds and carbonate host rocks (Harrison, 1972; Harrison and Lange, 1983). Harrison and Reynolds (1979) reported that the sulfide minerals at Blacktail Mountain near Kalispell (fig. 1) commonly are concentrated in the most permeable parts of a green-bed unit, in coarse-grained siltite and gray to white quartzite laminae and beds, and, locally, sedimentary fluid-escape structures and mudcracks. Similarly, Braun and Lange (1984) reported that the distribution of mineralized sandstone in the middle part of the Spokane Formation about $15 \mathrm{mi}$ northwest of the study area (and $15 \mathrm{mi}$ northeast of Lincoln) (fig. 1) was controlled by permeability of the host strata. Directly west of the study area, Lange and others (1987) found mineralized carbonate rocks to be composed of oolitic, intraclastic, and (or) algal-laminated limestone or pelletal calcareous siltstone; these rocks probably afforded good permeability immediately following their deposition. Mineralized carbonate rocks of the Helena Formation at Red Mountain, north of Lincoln (fig. 1), also are oolitic (Lange and Eby, 1981).

2. Minerals commonly found in strata-bound copper deposits are chalcocite, bornite, chalcopyrite, and pyrite, which may be zoned in the order presented. Lead and zinc generally are present only in minor amounts. The principal copper minerals in the Belt strata are chalcocite, bornite, digenite, and chalcopyrite; silver tends to accompany copper (Clark, 1971; Harrison, 1972; Trammel, 
1975). Bornite and chalcocite were the principal coppersulfide minerals found in the green beds at Blacktail Mountain, with only trace amounts of chalcopyrite and covellite (Harrison and Reynolds, 1979). In carbonate strata along Interstate Highway 15 west of the study area, Lange and others (1987) reported chalcocite, covellite, and bornite as the most abundant minerals, associated with lesser amounts of chalcopyrite, pyrite, and galena. Chalcopyrite was the chief mineral at one locality west of the highway, and Lange and Eby (1981) found it to be the most common mineral in the carbonate strata at Red Mountain. Near Interstate Highway 15, Lange and Eby (1981) also reported the existence of quartz veins that contain copper- and silver-sulfide minerals plus or minus barite and occupy steeply dipping faults of possible Late Cretaceous age. The minerals probably were remobilized from the Proterozoic occurrences.

3. The lack of nearby associated igneous rocks is one of the principal criteria for defining sediment-hosted strata-bound deposits. Strata of the Belt Supergroup generally lack volcanic or intrusive rocks that could have supplied epigenetic copper- and silver-sulfides present in the strata-bound deposits and occurrences.

4. The sulfide minerals are disseminated in the host rocks. In the strata-bound deposits of western Montana, sulfides are disseminated in green argillites, siltites, or quartzites (Harrison, 1972; Trammel, 1975). They do not form massive sulfide deposits.

5. The host strata commonly contain sedimentary structures indicative of nearshore marine environments and may contain evaporite minerals. The carbonate strata west of the study area contain oolitic grains, planar and hemispheroidal stromatolites, and evidence of evaporite minerals (Lange and others, 1987). Strata at the Blacktail Mountain drilling site include such features as mudcracks, rip-up clasts, and sediment deposited partly from suspension in shallow marine water (Harrison and Reynolds, 1979). These features, indicative of tidal-flat and shallow-shelf depositional environments, also are present in the Spokane Formation in the study area.

6. The strata-bound copper-bearing occurrences are associated with red clastic strata, commonly of nonmarine origin. In western Montana, units of red clastic strata alternate with units of green beds, with or without carbonate rocks.

7. No halo indicative of hydrothermal alteration is present. No halo of hydrothermal alteration is present in or near rocks of the study area.

8. Geochemical data on rocks were not reported by Gustafson and Williams (1981) in their summary of stratabound copper deposits found worldwide. At Blacktail Mountain, Harrison and Reynolds (1979) reported that most analyses of chip samples from green beds yielded anomalous copper values in the range of $1,500-5,000 \mathrm{ppm}$ (300 ppm in one sample) in mineralized rock, and background values of $10-50 \mathrm{ppm}$ in nonmineralized rock; corresponding silver values ranged from $<0.5$ to $5 \mathrm{ppm}$ in mineralized rock, but silver was not detected in other green beds. Lead values were $10-15 \mathrm{ppm}$, and zinc values $50-110$ ppm in both mineralized and nonmineralized green beds (at detection limit of $0.5 \mathrm{ppm}$ ). Immediately west of the study area, 13 samples from carbonate rocks (and one from phosphatic siltstone, discussed in the section of this report entitled "Other mineral resources") analyzed by Lange and others (1987) yielded the following concentrations: copper (average 5,080 ppm; range about 2-11,000 ppm), silver (average $12 \mathrm{ppm}$; range from $<0.5 \mathrm{ppm}$ [not detectable] to $29 \mathrm{ppm})$. High values of molybdenum, lead, and cadmium also were detected.

9. Several stream-sediment geochemical criteria that are useful in the assessment of potential for stratabound copper-silver sulfide deposits were presented by Harrison and others (1986) in a resource appraisal of the Wallace $1^{\circ} \times 2^{\circ}$ topographic quadrangle (about $50 \mathrm{mi}$ west of Lincoln, fig. 1), Montana and Idaho. They found that stream-sediment samples in drainages near known stratabound, copper-silver sulfide occurrences contained anomalous amounts of copper, with or without silver or lead. None, however, contained anomalous amounts of bismuth, molybdenum, antimony, or zinc.

In the Sleeping Giant Wilderness Study Area, mineralized green beds and carbonate strata of the Spokane Formation have the general characteristics of strata-bound copper-sulfide mineralization described in characteristics 1-7. The geochemical characteristics, however, differ and are discussed next. Strata of the Spokane Formation in the western part of the study area are contiguous with the green beds and copper-bearing limestone strata studied by I.M. Lange and associates along Interstate Highway 15. Prospects exist in these strata in and adjacent to the western part of the study area (pl. 1).

Two limestone samples from the study area were analyzed spectrographically and chemically, but no anomalous concentrations of elements were detected in either sample. One of the samples is from lowermost strata of the Spokane Formation (pl. 1, locality 20R), the other from the uppermost strata of the underlying Greyson Formation (pl. 1, locality 21R); these strata are conformable and closely related in depositional environments. Peters and Winters (1988) reported no anomalous concentrations of elements in two limestones samples from the Spokane Formation obtained within the study area, but reported anomalous copper and silver in a sample from about one-half mile west of the study area.

Two samples of quartz vein material from a prospect in the westernmost part of the study area (pl. 1, localities 33R, 34R; table 3) yielded no anomalous concentrations of elements. 
The geochemical data of this report (table 3) and that of the USBM (this report; Peters and Winters, 1988) show that green beds (including thin quartzite units in associated red beds) and limestones of the Spokane Formation within or near the study area do not everywhere contain anomalous concentrations of copper, silver, or associated elements. Mineralized zones within specific rock units are dispersed. Strata-bound mineralized rock in the model area of Blacktail Mountain, described earlier, forms lenticular or tonguelike zones, the distribution of which probably was determined by permeability of the host strata (Reynolds and Harrison, 1983; Harrison and others, 1986). In a similar manner, the distribution of anomalous values for copper, silver, and associated elements in rocks of the study area is expectedly discontinuous. Further, within the study area, carbonate strata in the Greyson and Spokane Formations, and probably green-bed units as well, are lenticular. Peters and Winters (1988) and Peters (1989) postulated that the copper and associated elements in the green beds were incorporated therein at the same time the beds were originally laid down (not introduced later), and that the local anomalous concentrations of elements represent their subsequent migration. This idea concerning copper concentration does not change the observations stated in the present report or conclusions concerning mineral resource potential of the study area.

Geochemical analysis of unconsolidated materials showed anomalous values of 200-1,000 ppm copper in heavy-mineral concentrate samples from some streams that drain across the Spokane Formation in the western part of the study area. Silver values of 0.7-1.5 ppm were detected in heavy-mineral concentrate samples in some of the streams that flow across the Spokane Formation, from which the silver probably was derived. These values are slightly above or at the detection limit $(0.5 \mathrm{ppm})$ for silver.

\section{Resource Potential}

The mineral resource potential for copper and silver in strata-bound deposits in green beds (including thin quartzite units in associated red beds) and limestone of the Spokane Formation in the outlined westernmost part of the Sleeping Giant Wilderness Study Area is rated as moderate, at a certainty level of $\mathrm{C}$. The mineral resource potential for copper and silver in strata-bound deposits of green beds (including thin quartzite units in associated red beds) and limestone in the rest of the Spokane Formation in the study area is rated as low, at a certainty level of C. A higher level of certainty would require additional geochemical sampling. The mineral resource potential for copper and silver in strata-bound deposits of green beds and limestone in the other formations in the study area is rated as low, at a certainty level of $\mathrm{D}$.

\section{Other Mineral Resources}

\section{Gold in Placer Deposits}

Gold was recovered by the USBM from placer deposits in the easternmost part of the study area, constituting an inferred subeconomic resource (see section of this report entitled "Identified resources"). Upstream 10-15 mi from the study area, near Canyon Ferry Lake (fig. 1), terrace deposits ("bars") along the Missouri River have yielded gold (Pardee and Schrader, 1933), and small placering operations are currently active there (Lawson, 1987). Similar terrace deposits exist within the easternmost part of the study area, in map unit Qac (pl. 1), and contain the gold resources identified by the USBM. Gold in the terrace deposits 15-20 mi upstream from the study area likely came from lodes present north of the river (Pardee and Schrader, 1933); the amount of gold in the placers probably would decrease rapidly downstream. Terrace deposits east of the study area have been quarried, and although samples of the basal gravels were collected and analyzed for gold, no gold was detected (Reynolds and Close, 1984; Close and Rigby, 1984).

No lode deposits that could have yielded placer gold occur in or near the Sleeping Giant Wilderness Study Area. Hence, the mineral resource potential for gold in placer deposits, other than in map unit Qac, in the study area is rated as low, at a certainty level of $\mathrm{D}$.

\section{Sapphires in Placer Deposits}

Sapphires have not been found in or adjacent to the wilderness study area. The USBM sampled the terrace deposits ("bars") in the eastern part of the study area, along the Missouri River, but found no sapphires (see section of this report entitled "Identified resources"). Reynolds and Close (1984) and Close and Rigby (1984) reported no recovery of sapphires from terrace deposits east of the study area, in the Gates of the Mountains Wilderness; the terraces were examined for sapphires at the same time as they were examined for gold. Close and Rigby (1984, p. 6, 16) reported that a few sapphires were mined from a Missouri River terrace deposit about $5 \mathrm{mi}$ south of the Sleeping Giant Wilderness Study Area, although they found no records of sapphire production.

Sapphires have been recovered from terrace deposits 15-20 mi upstream from the study area (Pardee and Schrader, 1933), and small placering operations are currently active in that area (Zeihen, 1987). A few sapphires have been found in igneous dikes in the general vicinity of the presently active placering operations; Kunz (1893) and Pardee and Schrader (1933) believed the dikes to be the source of the placer sapphires. Mertie and others (1951), however, stated that the dikes were too few to have supplied the quantity of sapphires recovered from the unconsolidated deposits. They postulated instead that the sapphires were 
derived from contact-metamorphic rocks formed in the roof zone of a granitic intrusive that crops out upstream of the placer deposits, and that these lode deposits have been entirely removed by erosion. No sapphire-bearing dikes are present within the study area, nor are sapphire-bearing contact-metamorphic rocks.

The mineral resource potential for sapphires in placer deposits of the Sleeping Giant Wilderness Study Area is rated as low, at a certainty level of $\mathrm{D}$.

\section{Phosphate}

The Lower Permian Phosphoria Formation is the host for minable phosphate in western Montana. The formation is only a few feet thick in the study area, where it crops out in thin, thrust-faulted slivers of rock, and consists mainly of chert and cherty sandstone; it lacks phosphorite. The Phosphoria Formation in the Sleeping Giant Wilderness Study Area is rated as having no resource potential for phosphate, at a certainty level of $D$.

A 0.25 - to 1-in.-thick peloidal phosphorite bed is present locally in the lower part of the Spokane Formation along Interstate Highway 15, about $2 \mathrm{mi}$ west of the wilderness study area (fig. 1; pl. 1) (Gulbrandsen, 1966; Lange and Sherry, 1986; Lange and others, 1987). The phosphate bed has never been mined and is much too thin and discontinuous to contain significant resources of phosphate. The phosphate bed was not found in the study area, although it could be present in the westernmost part of the area and have gone undetected. The mineral resource potential for phosphate in the Spokane Formation in the Sleeping Giant Wilderness Study Area is rated as low, at a certainty level of $\mathrm{D}$.

\section{Diatomite}

Diatomite is a porous, lightweight sedimentary rock composed almost entirely of the microscopic shells of diatoms, which are single-celled algae. The predominant use of diatomite in the United States is as a filtering agent (Barron, 1987). Diatomite in the study area is pale yellowish gray and forms poorly exposed discontinuous lenticular layers a few tenths of an inch thick within sediments deposited from glacial lake Great Falls (map unit Qs, pl. 1). The lake formed when a continental ice sheet dammed the Missouri River near Great Falls (Calhoun, 1906), backing water into the entrenched valley occupied by the river in the study area (Robinson and McCallum, 1991) and farther south into the area of the Missouri River north of Helena (Schmidt, 1986). The mineral resource potential for diatomite in the Sleeping Giant Wilderness Study Area is low, at a certainty level of $\mathrm{D}$.

\section{Decorative Stone}

Decorative stone (dimension stone) is naturally occurring rock that is selected, shaped, or cut into blocks, slabs, or other specified shape for use in structures such as pavements, walkways, fireplaces, or walls of buildings. Slabs of dark gray siltite from the lower part of the Greyson Formation currently are being quarried on claims in the valley of Towhead Gulch, as discussed by the USBM in the "Identified resources" section of this report. Rock like that being quarried also occurs in the lower part of the Greyson directly adjacent to the identified resource of slate. Directly adjacent to the identified resource of slate, the Sleeping Giant Wilderness Study Area has a high resource potential for decorative slate, at a certainty level of $\mathrm{D}$. The eastern limit of resource potential for decorative slate is located only approximately due to poor exposures. Lower Greyson strata with properties similar to those of rock along Towhead Creek also are present in the north-central part of the study area (fig. $2 ;$ pl. 1), where the resource potential for decorative slate is rated as high, with a certainty level of $\mathrm{C}$. The resource potential for decorative stone in exposed rock in the remainder of the Sleeping Giant Wilderness Study Area is rated as low, at a certainty level of $\mathrm{C}$.

\section{Energy Resource Potential}

\section{Uranium}

A National Uranium Resource Evaluation (NURE) program, under the sponsorship of the U.S. Department of Energy, was carried out during the late 1970's and early 1980 's to assess uranium resources of the United States. The Sleeping Giant Wilderness Study Area lies within parts of two regions that were evaluated separately. The part of the study area east of $112^{\circ}$ longitude is within the White Sulphur Springs $1^{\circ} \times 2^{\circ}$ quadrangle (scale, 1:250,000), and that west of $112^{\circ}$ is within the Butte $1^{\circ} \times 2^{\circ}$ quadrangle. No samples were collected from the study area during the evaluation of the White Sulphur Springs quadrangle (D'Andrea and others, 1981); the study area is in a part of the quadrangle that was designated as unevaluated by Dodd and others (1982).

West of $112^{\circ}$ longitude, in the Butte quadrangle, no anomalous concentrations of uranium were found (Broxton, 1980). As part of the NURE evaluation, Van Eeckhout (1980) and Sartoris and others (1982) concluded that the region in which the study area lies is north of those parts of the Butte quadrangle that are considered favorable for uranium deposits. They stated that strata of the Belt Supergroup, which constitute nearly all the rocks west of $112^{\circ}$ longitude in the study area as well as about one-third of those east of that longitude, lack many of the recognition criteria favorable for uranium in sedimentary environments.

The resource potential for uranium in the Sleeping Giant Wilderness Study Area is rated as low, at a certainty level of C. Geochemical sampling for uranium east of $112^{\circ}$ longitude in the study area would be necessary to achieve a higher level of certainty. 
Table 4. Vitrinite reflectance and pyrolysis (Rock-Eval method) of shale in the vicinity of the Sleeping Giant Wilderness Study Area, Lewis and Clark County, Montana

$\left[R_{o}\right.$, mean optical reflectance of visually identifiable vitrinite-huminite particles in oil; $T_{\max }$, furnace temperature corresponding to the time during pyrolysis when the yield of hydrocarbons is at a maximum; $S_{1}$, volatilized hydrocarbons existing in sample; $S_{2}$, hydrocarbons pyrolitized from kerogen; $S_{3}$, carbon dioxide; TOC, total organic carbon. Vitrinite reflectance analyst, M.J. Pawlewicz, USGS; pyrolysis analyst, T.A. Daws, USGS]

\begin{tabular}{|c|c|c|c|c|c|}
\hline $\begin{array}{c}\text { Locality } \\
\text { No. } \\
\text { (plate 1) }\end{array}$ & $\begin{array}{c}\text { Sample } \\
\text { No. }\end{array}$ & $\begin{array}{c}\text { Latitude } \\
\text { deg-min-sec }\end{array}$ & $\begin{array}{c}\text { Longitude } \\
\text { deg-min-sec }\end{array}$ & Formation & Lithology \\
\hline $1 \mathrm{~V}$ & 87MTz190 & $46-52-31$ & $111-58-44$ & Blackleaf Formation & Shale, olive-black \\
\hline $2 \mathrm{~V}$ & 87MTz198 & $46-59-23$ & $112-01-17$ & Marias River Shale & Shale, dark-gray \\
\hline $3 \mathrm{~V}$ & 87MTz199 & $46-59-49$ & $112-00-32$ & Blackleaf Formation & Shale, dark-gray \\
\hline
\end{tabular}

\begin{tabular}{|c|c|c|c|c|c|c|}
\hline & \multirow{3}{*}{$\begin{array}{c}\begin{array}{c}\text { Vitrinite } \\
\text { reflectance }\end{array} \\
\begin{array}{c}\text { percent } \\
R_{0}\end{array}\end{array}$} & \multicolumn{4}{|c|}{ Pyrolysis } & \multirow{3}{*}{$\begin{array}{c}\text { Percent } \\
\text { TOC }\end{array}$} \\
\hline & & \multirow{2}{*}{$\frac{{ }^{\circ} \mathrm{C}}{\mathrm{T}_{\max }}$} & \multicolumn{3}{|c|}{ milligram/gram } & \\
\hline & & & $\mathrm{S}_{1}$ & $\mathrm{~S}_{2}$ & $\mathrm{~S}_{3}$ & \\
\hline $1 \mathrm{~V}$ & 1.40 & 408 & 0.01 & 0.06 & 0.53 & 1.01 \\
\hline $2 \mathrm{~V}$ & 0.88 & 443 & 0.10 & 0.73 & 0.60 & 1.38 \\
\hline $3 \mathrm{~V}$ & 1.20 & 446 & 0.08 & 0.49 & 0.61 & 1.44 \\
\hline
\end{tabular}

\section{Petroleum Resources}

Several lines of evidence lead to the conclusion that the Sleeping Giant Wilderness Study Area has a Iow resource potential for oil and for gas. Thermal properties of potential source rocks in the study area indicate significant heating, a thick igneous sill in the eastern part of the area post-dates thrusting, and exploration test holes nearby were unsuccessful and have been plugged and abandoned. In addition, strata exposed in the study area have a total organic content that is below the threshold value considered favorable for generation of hydrocarbons.

Potential reservoir rocks for hydrocarbons in the vicinity of the Sleeping Giant Wilderness Study Area include carbonate strata of the Upper Devonian Jefferson Formation and the Mississippian Madison Group, sandstone of the Pennsylvanian Quadrant Sandstone, and Cretaceous sandstones. Only the Cretaceous units are exposed within the study area but all units are interpreted to lie beneath the Eldorado thrust fault, concealed under Middle Proterozoic Belt strata (see cross section, pl. 1). Potential hydrocarbon source rocks exposed locally near the edge of the study area are shales of the Cretaceous Blackleaf and Marias River Formations. Vitrinite reflectance $\left(R_{\mathrm{o}}\right)$ measured on shale from the Blackleaf Formation (table 4; pl. 1, localities 1V and $3 \mathrm{~V}$ ) indicate mature organic matter (M.J. Pawlewicz, USGS, written commun., 1988). The values correspond to those indicative of the uppermost end of the oil-generation window and to those of the wet- to dry-gas windows that overlap the uppermost end of the oil-generation window (Dow and O'Connor, 1982, diagram showing zones of petroleum generation and destruction, p. 145). Vitrinite reflectance measured on a sample from the Marias River Shale (table 4; pl. 1, locality 2V) also determined the presence of mature organic matter (M.J. Pawlewicz, USGS, written commun., 1988). The value lies in the middle of the oil-generation window, but has only sparse, low-rank organic material, which makes the reflectance determination unreliable.

Values of organic richness determined by pyrolysis may be used to evaluate source-rock quality. Two minimum values of organic richness above which rocks are considered favorable as source rocks for hydrocarbons are as follows: total organic content of 1 percent and hydrocarbon content of $2 \mathrm{mg} / \mathrm{g}$ (milligram per gram) $\left(S_{1}+S_{2}\right.$, table 4 ) (Poole and Claypool, 1984). The total organic content of all three samples from the vicinity of the study area are at, or somewhat above, the minimum values of favorability (table 4). These low values complement the thermal reflectance values that indicate an advanced stage of thermal maturity for the (reliable) samples from localities $1 \mathrm{~V}$ and $3 \mathrm{~V}$. All three samples yielded less than $2 \mathrm{mg} / \mathrm{g}\left(\mathrm{S}_{1}+\mathrm{S}_{2}\right)$ during pyrolysis, indicating an inadequate potential for hydrocarbons. Although the reflectance value determined for the sample from locality $2 \mathrm{~V}$ is considered unreliable, the total organic content and the $S_{1}+S_{2}$ value for this sample is well below the minimum value considered favorable for hydrocarbon potential.

Other potential source rocks are exposed directly east of the Sleeping Giant Wilderness Study Area in the Gates of the Mountains Wilderness. Down-structure viewing, from 
east to west, indicates that rocks like those of the Gates of the Mountains Wilderness lie at depth beneath the Sleeping Giant Wilderness Study Area (see cross section, pl. 1). Potential source rocks of the Gates of the Mountains Wilderness are of Devonian, Mississippian, Jurassic, and Cretaceous age. From these strata Reynolds and Close (1984) evaluated unweathered samples for organic carbon content, thermal pyrolysis level, and vitrinite reflectance properties at all structural levels and found the strata to have passed through the temperature range of oil and wet gas generation and to have only a slight potential for dry natural gas. At depth beneath the surface of the Sleeping Giant Wilderness Study Area, these strata would be expected to have similar thermal histories. Perry and others (1983, p. G16) earlier had rated the Gates of the Mountains Wilderness as having zero oil potential and low to zero gas potential. For an area a few miles east of the Gates of the Mountains Wilderness, Longden and others (1988) concluded that strata have passed through the temperature range of oil and wet gas generation and probably through the dry gas range as well.

In an evaluation of the petroleum resource potential of the Montana thrust belt, Perry (1988) divided the belt into geologic regions ("plays") based on structural characteristics. The study area lies at the southern end of the "Eldorado-Lewis subthrust play" and was characterized by regionally high heat-flow conditions during the Late Cretaceous and early Tertiary (M.R. Reynolds, oral commun., in Perry, 1988, p. 15), corresponding to widespread intrusive and extrusive igneous rocks in west-central Montana.

Many sills have intruded strata of the Sleeping Giant Wilderness Study Area. Some of these predate thrusting and, although they may have heated the associated sediments beyond the temperature range favorable for preservation of oil and (or) gas, fracturing of strata during later thrusting may have created pores into which hydrocarbons could have been introduced after thrusting. However, our field studies show that the major rhyodacite sills of the study area were intruded after thrusting took place. These igneous rocks would have introduced significant heat to the rocks, including the potential reservoir and source rocks concealed beneath the Eldorado thrust plate. Such heating likely was a major cause of the high reflectance values (table 4) determined on shale adjacent to the study area and is not a favorable factor for preservation of oil or gas beneath the study area.

Exploration test holes drilled in the vicinity of the study area have failed to find significant hydrocarbons. The Getty Oil Co. 3-10 Federal (fig. 1) was drilled about $12 \mathrm{mi}$ east-southeast of the Sleeping Giant Wilderness Study Area (adjacent to the Gates of the Mountains Wilderness), bottomed in Cambrian strata at a depth of $13,731 \mathrm{ft}$, and was plugged and abandoned in 1982 (Bryant, 1985, p. 129). The hole was drilled into the major fold that plunges westward beneath the surface of the Gates of the Mountains Wilderness (Reynolds and Close, 1984).

The UNOCAL 1-B30 Federal test hole (fig. 1) drilled about 10 mi directly west of the Sleeping Giant Wilderness Study Area was plugged and abandoned in early 1990. This hole was spudded in strata of the Middle Proterozoic Spokane Formation. It penetrated the Eldorado thrust fault at a depth of about $12,200 \mathrm{ft}$, where it entered Cretaceous strata beneath the thrust fault and bottomed in Mississippian dolostone and limestone at a depth of $17,818 \mathrm{ft}$ (W.J. Perry, Jr., written commun., 1990).

The anticlinal structure in the lower thrust plate beneath the study area is based on northwestward projection of a complex anticline mapped by Robinson and McCallum (1991) directly southeast of the southeast corner of the study area, and by Robinson and others (1969) farther southeast in the Upper Holter Lake quadrangle. The anticline plunges northwest at a low angle (pl. 1). Potential trapping structures for hydrocarbons are open to the surface at the erosional limit of the Eldorado thrust fault in the southeasternmost part of the study area and farther southeast. No seismic data exist that would aid in delineating the internal characteristics of the fold beneath the Eldorado plate.

Our data indicate that rocks of the Sleeping Giant Wilderness Study Area have a low resource potential for oil, at a certainty level of $\mathrm{C}$ : available information gives a good indication of the level of resource potential. The study area is rated as having a low resource potential for gas, at a certainty level of $\mathrm{C}$.

\section{Geothermal Energy}

No known geothermal resource area (KGRA) exists within the region of the Sleeping Giant Wilderness Study Area, according to the studies of Muffler (1979) and Sonderegger and Bergantino (1981). No hot springs, or tufa deposits of former hot springs, occur within or adjacent to the study area. The igneous intrusive bodies present in the study area are sills that cooled long ago, and thus they are unable to supply heat to ground water that may circulate beneath the area.

The Sleeping Giant Wilderness Study Area is rated as having Iow potential for geothermal resources, at a certainty level of C. A higher level of certainty would require specific studies, such as heat flow measurements, to better evaluate the potential for geothermal resources.

\section{REFERENCES CITED}

Barron, J.S., 1987, Diatomite-Environmental and geologic factors affecting its distribution, in Hein, J.R., ed., Siliceous sedimentary rock-hosted ores and petroleum: New York, Van Nostrand Reinhold Co., p. 164-178. 
Benjamin, D.A., and Gale, George, 1984, MLA costing procedures for classification of mineral resource: unpublished report available at Western Field Operations Center, U.S. Bureau of Mines, E. 360 Third Avenue, Spokane, WA 99202, 60 p.; includes BASIC computer program.

Billingsley, P.R., and Locke, A., 1939, Structure of ore deposits in the continental framework: New York, American Institute of Mining and Metallurgical Engineers, 51 p.Braun, E.R., and Lange, I.M., 1984, Organic control of sandstone-hosted copper-silver mineralization in the Spokane Formation near Rogers Pass, western Montana, in McBane, J.D., and Garrison, P.B., eds., Northwest Montana and adjacent Canada: Montana Geological Society 1984 Field Conference and Symposium, p. 305-313.

Bregman, M.L., 1976, Change in tectonic style along the Montana thrust belt: Geology, v. 4, p. 775-778.

1981, Structural geology of the Sheep Creek and Rattlesnake Mountain quadrangles, Lewis and Clark County, Montana: Montana Bureau of Mines and Geology Geologic Map 26, scale 1:24,000, pamphlet.

Broxton, D.E., 1980, Uranium hydrogeochemical and stream sediment reconnaissance data release for the Butte NTMS quadrangle, Montana, including concentrations of forty-two additional elements: U.S. Department of Energy Open-File Report GJBX-129(80), 207 p.

Bryant, M.B., 1985, Wells drilled for oil and gas in western Montana and the Idaho overthrust belt, in Tonnsen, J.J., ed., Montana oil and gas fields symposium: Billings, Montana Geological Society, p. 123-135.

Calhoun, F.H.H., 1906, The Montana lobe of the Keewatin ice sheet: U.S. Geological Survey Professional Paper 50, 62 p.

Clark, A.L., 1971, Stratabound copper sulfides in the Precambrian Belt Supergroup, northern Idaho and northwestern Montana, U.S.A.: Proceedings of International Mineralogical Association General Meeting, 7th International Association on the Genesis of Ore Deposits, Tokyo-Kyoto Meeting, 1970, p. 261-267.

Close, T.J., and Rigby, J.G., 1984, Mineral investigation of the Gates of the Mountains Wilderness Study Area, Lewis and Clark County, Montana: U.S. Bureau of Mines Open File Report MLA 3-84, 20 p.

Crock, J.G., Briggs, P.H., Jackson, L.L., and Lichte, F.E., 1987, Analytical methods for the analysis of stream sediments and rocks from wilderness study areas: U.S. Geological Survey Open-File Report 87-84, p. 22-28.

D'Andrea, R.F., Jr., R.J. Zinkl, Shettel, D.L., Jr., Langfeldt, S.L., and Youngquist, C.A., 1981, Uranium hydrogeochemical and stream sediment reconnaissance of the White Sulphur Springs NTMS quadrangle, Montana: U.S. Department of Energy Open-File Report GJBX-266(81), 184 p.

Dodd, S.P., Wopat, M.A., and Robins, J.W., 1982, White Sulphur Springs quadrangle: U.S. Department of Energy, Open-File Report PGJ/F-136(82), 99 p.

Dow, W.G., and O'Connor, D.I., 1982, Kerogen maturity and type by reflected light microscopy applied to petroleum exploration, in How to assess maturation and paleotemperatures: Society of Economic Paleontologists and Mineralogists Short Course No. 7, p. 133-157.
Goudarzi, G.H., 1984, Guide to preparation of mineral survey reports on public lands: U.S. Geological Survey Open-File Report 84-787, 30 p.

Grimes, D.J., and Marranzino, A.P., 1968, Direct-current arc and alternating-current spark emission spectrographic field methods for the semiquantitative analysis of geologic materials: U.S. Geological Survey Circular 591, 6 p.

Gulbrandsen, R.A., 1966, Precambrian phosphorite in the Belt Series in Montana, in Geological Survey research 1966: U.S. Geological Survey Professional Paper 550-D, p. D199-D202.

Gustafson, L.B., and Williams, Neil, 1981, Sediment-hosted stratiform deposits of copper, lead, and zinc, in Skinner, B.J., ed., Economic Geology seventy-fifth anniversary volume, 1905-1980: Economic Geology Publishing Co., p. 139-178.

Harrison, J.E., 1972, Precambrian Belt basin of northwestern United States-Its geometry, sedimentation, and copper occurrences: Geological Society of America Bulletin, v. 83, p. $1215-1240$.

1974, Copper mineralization in miogeosynclinal clastics of the Belt Supergroup, northwestern United States, in Bartholomew, Paul, ed., Gisements Stratiformes et Provinces Cuprifères: Liege, Belgium, Geological Society of Belgium, p. 353-366.

Harrison, J.E., Domenico, J.A., and Leach, D.L., 1986, Resource appraisal map for stratabound copper-silver deposits in the Wallace $1^{\circ} \times 2^{\circ}$ quadrangle, Montana and Idaho: U.S. Geological Survey Miscellaneous Investigations Series Map I-1509-F, scale 1:250,000.

Harrison, J.E., and Reynolds, M.W., 1979, Preliminary geology of the Blacktail Mountain drilling site, Flathead County, Montana: U.S. Geological Survey Open-File Report 79-938, $36 \mathrm{p}$.

Harrison, J.M, and Lange, I.M., 1983, Stratabound copper occurrences in green beds of the Belt Supergroup, western Montana; field guide of trip 5, in Hobbs, S.W., ed., Guide to field trips, Belt symposium II: Missoula, University of Montana Department of Geology, p. 94-104.

Hayes, T.S., and Einaudi, M.T., 1987, Genesis of the Spar Lake strata-bound copper-silver deposit, Montana-Part I. Controls inherited from sedimentation and preore diagenesis: Economic Geology, v. 81, p. 1899-1931.

Kleinkopf, M.D., and Mudge, M.R., 1972, Aeromagnetic, Bouguer gravity, and generalized geologic studies of the Great Falls-Mission Range area, northwestern Montana: U.S. Geological Survey Professional Paper 726-A, 19 p., 2 maps, scale $1: 250,000$.

Knipling, E.B., 1969, Leaf reflectance and image formation on color infrared film, in Johnson, P.L., ed., Remote sensing in ecology: Athens, University of Georgia Press, p. 17-29.

Kunz, G.F., 1893, Precious stones, in Mineral resources of the United States, 1891: U.S. Geological Survey, Mineral Resources of the United States, p. 542-544.

Lange, I.M., and Eby, D.E., 1981, Stratabound copper-silverbearing oolitic deposits in the Belt Supergroup of Montana: Economic Geology, v. 76, p. 933-936.

Lange, I.M., Moore, J.N., and Braun, E.R., 1986, Geology and diagenetic aspects of the Canyon Creek sandstone and Wolf Creek carbonate-hosted copper-silver deposits of the Belt 
Supergroup, northwestern Montana, U.S.A., in Craig, J.R., and others, eds., Mineral paragenesis: Athens, Greece, Theophrastus Publications, p. 411-442.

Lange, I.M., Moore, J.N., and Krouse, H.,R., 1987, Diagenesis and copper mineralization in carbonates in the Spokane Formation, Belt Supergroup, at Wolf Creek, Montana: Economic Geology, v. 82, p. 1334-1347.

Lange, I.M., and Sherry, R.A., 1986, Nonmassive sulfide deposits in the Late Precambrian Supergroup of western Montana, in Roberts, S.M., ed., Belt Supergroup, A guide to Proterozoic rocks in western Montana and adjacent areas: Montana Bureau of Mines and Geology Special Paper 94, p. 269-278.

Lawson, D.C., 1987, Directory of Montana mining enterprises for 1986: Montana Bureau of Mines and Geology Bulletin 126, $55 \mathrm{p}$.

Longden, M.R., Banowsky, B.R., and Woodward, L.A., 1988, Source rock evaluation of Heath formation (Mississippian) in Montana thrust belt: Oil and Gas Journal, v. 86, no. 19, p. 60-63.

Lyden, C.J., 1948, The gold placers of Montana: Montana Bureau of Mines and Geology Memoir 26, $152 \mathrm{p}$.

Maher, P.D., 1976, The geology of the Pineview area, Summit County, in Symposium on geology of the Cordilleran hinge line: Denver, Colo., Rocky Mountain Association of Geologists, p. 345-350.

Malcolm, M.J., and Carlson, R.R., 1990, Analytical results and sample locality map of stream sediments and heavy-mineral concentrate samples from the Sleeping Giant Wilderness Study Area (MT-075-111), Lewis and Clark County, Montana: U.S. Geological Survey Open-File Report 90-0469, $18 \mathrm{p}$.

Mertie, J.B., Jr., Fischer, R.P., and Hobbs, S.W., 1951, Geology of the Canyon Ferry quadrangle, Montana: U.S. Geological Survey Bulletin 972, $97 \mathrm{p}$.

Muffler, L.P.J., editor, 1979, Assessment of geothermal resources of the United States: U.S. Geological Survey Circular 790, $163 \mathrm{p}$.

O'Leary, R.M., and Meier, A.L., 1984, Analytical methods used in geochemical exploration: U.S. Geological Survey Circular 948 , p. 23-25.

Pardee, J.T., and Schrader, F.C., 1933, Metalliferous deposits of the greater Helena mining region, Montana: U.S. Geological Survey Bulletin 842, $318 \mathrm{p}$.

Perry, W.J., Jr., 1988, A review of the geology and petroleum resource potential of the Montana thrust belt, with a section on Geology of potential Mississippian reservoir rocks, disturbed belt sector of the Montana thrust belt: U.S. Geological Survey Open-File Report 88-450C, 28 p.

Perry, W.J., Jr., Rice, D.D., and Maughn, E.K., 1983, Petroleum potential of wilderness lands in Montana, in Miller, B.M., ed., Petroleum potential of wilderness lands in the western United States: U.S. Geological Survey Circular 902-G, p. G1-G23.

Peters, T.J., 1989, Stratabound base-metal and silver concentrations in green siltite and associated rocks of the Spokane Formation on Sleeping Giant Mountain, Lewis and Clark County, Montana: Geological Society of America Abstracts with Programs, v. 21, no. 5, Cordilleran and Rocky Mountain Sections, Spokane, Washington, p. 129.
Peters, T.J., and Winters, R.A., 1988, Mineral resources of the Sleeping Giant Study Area, Lewis and Clark County, Montana: U.S. Bureau of Mines Open File Report MLA 36-88, $54 \mathrm{p}$.

Poole, F.G., and Claypool, G.E., 1984, Petroleum source-rock potential and crude-oil correlation in the Great Basin, in Woodward, Jane, Meissner, F.F., and Clayton, J.L, eds., Hydrocarbon source rocks of the Greater Rocky Mountain region: Denver, Colo., Rocky Mountain Association of Geologists, p. 179-229.

Reynolds, M.W., 1979, Character and extent of basin-range faulting, western Montana and east-central Idaho, in Newman, G.W., and Goode, H.D., eds., RMAG-UGA-1979 basin and range symposium: Denver, Colo., Rocky Mountain Association of Geologists, p. 185-193.

Reynolds, M.W., and Close, T.J., 1984, Gates of the Mountains Wilderness and additions, Montana, in Marsh, S.P., Kropschot, S.J., and Dickinson, R.G., Wilderness mineral potential, Assessment of mineral-resource potential in U.S. Forest Service lands studied, 1964-1984: U.S. Geological Survey Professional Paper 1300, p. 705-708.

Reynolds, M.W., and Harrison, J.E., 1983, Supplement to abstract, in Connor, J.J., Domenico, J.A., Harrison, J.E., Reynolds, M.W., Rye, R.O., and Whelan, J.F., Addendum on greenbed copper occurrences in upper part of the Spokane Formation at the Blacktail Mountain drilling site near Lakeside, Montana, in Hobbs, S.W., ed., Guide to field trips, Belt symposium II: Missoula, University of Montana Department of Geology, p. 105-108.

Robinson, G.D., and McCallum, M.E., 1991, Preliminary geologic map of the Beartooth Mountain quadrangle, Lewis and Clark County, Montana: U.S. Geological Survey Open-File Report 91-0113, scale 1:24,000.

Robinson, G.D., McCallum, M.E., and Hays, W.H., 1969, Geologic map of the Upper Holter Lake quadrangle, Lewis and Clark County, - Montana: U.S. Geological Survey Geologic Quadrangle Map GQ-840, scale 1:24,000.

Rowan, L.C., Goetz, A.G.H., and Ashley, R.P., 1977, Discrimination of hydrothermally altered and unaltered rocks invisible and near-infrared multispectral images: Geophysics, v. 41, p. 522-535.

Rowan, L.C., Wetlaufer, P.H., Goetz, A.F.H., Billingsley, F.C., and Stewart, J.H., 1974, Discrimination of rock types and detection of hydrothermally altered areas in south-central Nevada by use of computer-enhanced ERTS images: U.S. Geological Survey Professional Paper 883, 35 p.

Sartoris, D.J., Gilmour, D.H., Salisbury, W.G., and McKee, C.J., 1982, National uranium resource evaluation, Butte quadrangle, Montana: U.S. Department of Energy OpenFile Report PGJ/F-064(82), 43 p.

Schmidt, R.G., 1972, Geologic map of the Wolf Creek quadrangle, Lewis and Clark County, Montana: U.S. Geological Survey Geologic Quadrangle Map GQ-974, scale 1:24,000.

1977, Geologic map of the Craig quadrangle, Lewis and Clark and Cascade Counties, Montana: U.S. Geological Survey Geologic Quadrangle Map GQ-1141, scale: $1: 24,000$.

1986, Geology, earthquake hazards, and land use in the Helena area, Montana-A review: U.S. Geological Survey Professional Paper 1316, 64 p. 
Sonderegger, J.L., and Bergantino, R.N., 1981, Geothermal resources of Montana: Montana Bureau of Mines and Geology Hydrogeologic Map HM-4, scale 1:1,000,000.

Taylor, H.A., Jr., 1985, Dimension stone, in Mineral facts and problems, 1985 edition: U.S. Bureau of Mines Bulletin 675, $956 \mathrm{p}$.

1988, Stone (dimension), in Mineral commodity summaries: U.S. Bureau of Mines, $193 \mathrm{p}$.

Trammel, J.W., 1975, Strata-bound copper mineralization in the Empire Formation and Ravalli Group, Belt Supergroup, Northwest Montana: Seattle, Wash., University of Washington, Ph.D. thesis, 70 p.

Tysdal, R.G., Reynolds, M.W., Carlson, R.R., Kleinkopf, M.D., Rowan, L.C., and Peters, T.J., 1990, Mineral resources of the Sleeping Giant Wilderness Study Area, Lewis and Clark County, Montana: U.S. Geological Survey Open-File Report 90-0410, 44 p.

U.S. Bureau of Mines and U.S. Geological Survey, 1980, Principles of a resource/reserve classification for minerals: U.S. Geological Survey Circular 831, 5 p.
U.S. Geological Survey, 1979, Aeromagnetic map of the Rogers Pass area, Montana: U.S. Geological Survey Open-File Report 80-244, scale 1:62,500.

1984, Aeromagnetic map of the Butte $1^{\circ} \times 3^{\circ}$ quadrangle, Montana: U.S. Geological Survey Open-File Report 84-0278, 7 sheets, scale 1:62,500.

Van Eeckhout, E.M., 1980, Utilizing the geochemical data from the national uranium resource evaluation (NURE) program-An evaluation of the Butte quadrangle, Montana: U.S. Department of Energy Open-File Report GJBX-58(81), $67 \mathrm{p}$

Wirth, D.W., 1985, Mineral patent examination Anson No. 1, Anson No. 2, Anson No. 3, building stone placer claims: U.S. Bureau of Land Management Mineral Report, Serial Number M-50642, 29 p.

Zeihen, L.G., 1987, The sapphire deposits of Montana, in Lawson, D.C., compiler, Directory of Montana mining enterprises for 1986: Montana Bureau of Mines and Geology Bulletin 126 , p. $28-40$. 


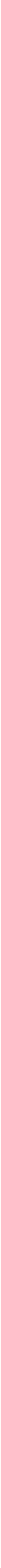


APPENDIX 


\section{DEFINITION OF LEVELS OF MINERAL RESOURCE POTENTIAL AND CERTAINTY OF ASSESSMENT}

\section{LEVELS OF RESOURCE POTENTIAL}

H HIGH mineral resource potential is assigned to areas where geologic, geochemical, and geophysical characteristics indicate a geologic environment favorable for resource occurrence, where interpretations of data indicate a high degree of likelihood for resource accumulation, where data support mineral-deposit models indicating presence of resources, and where evidence indicates that mineral concentration has taken place. Assignment of high resource potential to an area requires some positive knowledge that mineral-forming processes have been active in at least part of the area.

M MODERATE mineral resource potential is assigned to areas where geologic, geochemical, and geophysical characteristics indicate a geologic environment favorable for resource occurrence, where interpretations of data indicate reasonable likelihood for resource accumulation, and (or) where an application of mineral-deposit models indicates favorable ground for the specified type(s) of deposits.

L LOW mineral resource potential is assigned to areas where geologic, geochemical, and geophysical characteristics define a geologic environment in which the existence of resources is permissive. This broad category embraces areas with dispersed but insignificantly mineralized rock, as well as areas with little or no indication of having been mineralized.

N NO mineral resource potential is a category reserved for a specific type of resource in a well-defined area.

$U$ UNKNOWN mineral resource potential is assigned to areas where information is inadequate to assign a low, moderate, or high level of resource potential.

\section{LEVELS OF CERTAINTY}

A Available information is not adequate for determination of the level of mineral resource potential.

B Available information only suggests the level of mineral resource potential.

C Available information gives a good indication of the level of mineral resource potential.

D Available information clearly defines the level of mineral resource potential.

\begin{tabular}{|c|c|c|c|}
\hline A & B & C & $D$ \\
\hline \multirow{4}{*}{ UNKNOWN POTENTIAL } & $\begin{array}{c}\text { H/B } \\
\text { HIGH POTENTIAL }\end{array}$ & $\begin{array}{c}\text { H/C } \\
\text { HIGH POTENTIAL }\end{array}$ & $\begin{array}{c}\text { H/D } \\
\text { HIGH POTENTIAL }\end{array}$ \\
\hline & $\begin{array}{c}\text { M/B } \\
\text { MODERATE POTENTIAL }\end{array}$ & $\begin{array}{c}\text { MC } \\
\text { MODERATEPOTENTIAL }\end{array}$ & $\begin{array}{c}\text { MD } \\
\text { MODERATE POTENTIAL }\end{array}$ \\
\hline & $\begin{array}{c}\text { L/B } \\
\text { LOW POTENTIAL }\end{array}$ & $\begin{array}{c}\text { UC } \\
\text { LOW POTENTIAL }\end{array}$ & $\begin{array}{c}\text { U/D } \\
\text { LOW POTENTIAL }\end{array}$ \\
\hline & & & $\begin{array}{c}\text { N/D } \\
\text { NO POTENTIAL }\end{array}$ \\
\hline
\end{tabular}

\section{LEVEL OF CERTAINTY}

Abstracted with minor modifications from:

Taylor, R.B., and Steven, T.A., 1983, Definition of mineral resource potential: Economic Ceology, v. 78, no. 6, p. 1268-1270.

Taylor, R.B., Stoneman, R.J., and Marsh, S.P., 1984, An assessment of the mineral resource potential of the San Isabel National forest, south-central Colorado: U.S. Geological Survey Bulletin 1638, p. 40.42.

Goudarzi, G.H., compiler, 1984, Guide to preparation of mineral survey reports on public lands: U.5. Ceological Survey Open-File Report 84-0787, p. 7, 8. 


\section{RESOURCE/RESERVE CLASSIFICATION}

\begin{tabular}{|c|c|c|c|c|c|}
\hline & \multicolumn{3}{|c|}{ IDENTIFIED RESOURCES } & \multirow{2}{*}{\multicolumn{2}{|c|}{$\frac{\text { UNDISCOVERED RESOURCES }}{\text { Probability Range }}$}} \\
\hline & \multicolumn{2}{|c|}{ Demonstrated } & \multirow{2}{*}{ Inferred } & & \\
\hline & Measured & Indicated & & Hypothetical & Speculative \\
\hline ECONOMIC & Res & & Inferred Reserves & & \\
\hline $\begin{array}{l}\text { MARGINALLY } \\
\text { ECONOMIC }\end{array}$ & Margine & Reserves & $\begin{array}{c}\text { Inferred } \\
\text { Marginal Reserves }\end{array}$ & & \\
\hline $\begin{array}{c}\text { SUB- } \\
\text { ECONOMIC }\end{array}$ & $\begin{array}{r}\text { Demo } \\
\text { Subeconon }\end{array}$ & $\begin{array}{l}\text { trated } \\
\text { Resources }\end{array}$ & $\begin{array}{c}\text { Inferred } \\
\text { Subeconomic } \\
\text { Resources }\end{array}$ & & \\
\hline
\end{tabular}

Major elements of mineral resource classification, excluding reserve base and inferred reserve base. Modified from McKelvey, 1972, Mineral resource estimates and public policy: American Scientist, v.60, p.32-40, and U.S. Bureau of Mines ànd U.S. Geological Survey, 1980, Principles of a resource/reserve classification for minerals: U.S. Geological Survey Circular 831, p.5. 
GEOLOGIC TIME CHART

Terms and boundary ages used by the U.S. Geological Survey in this report

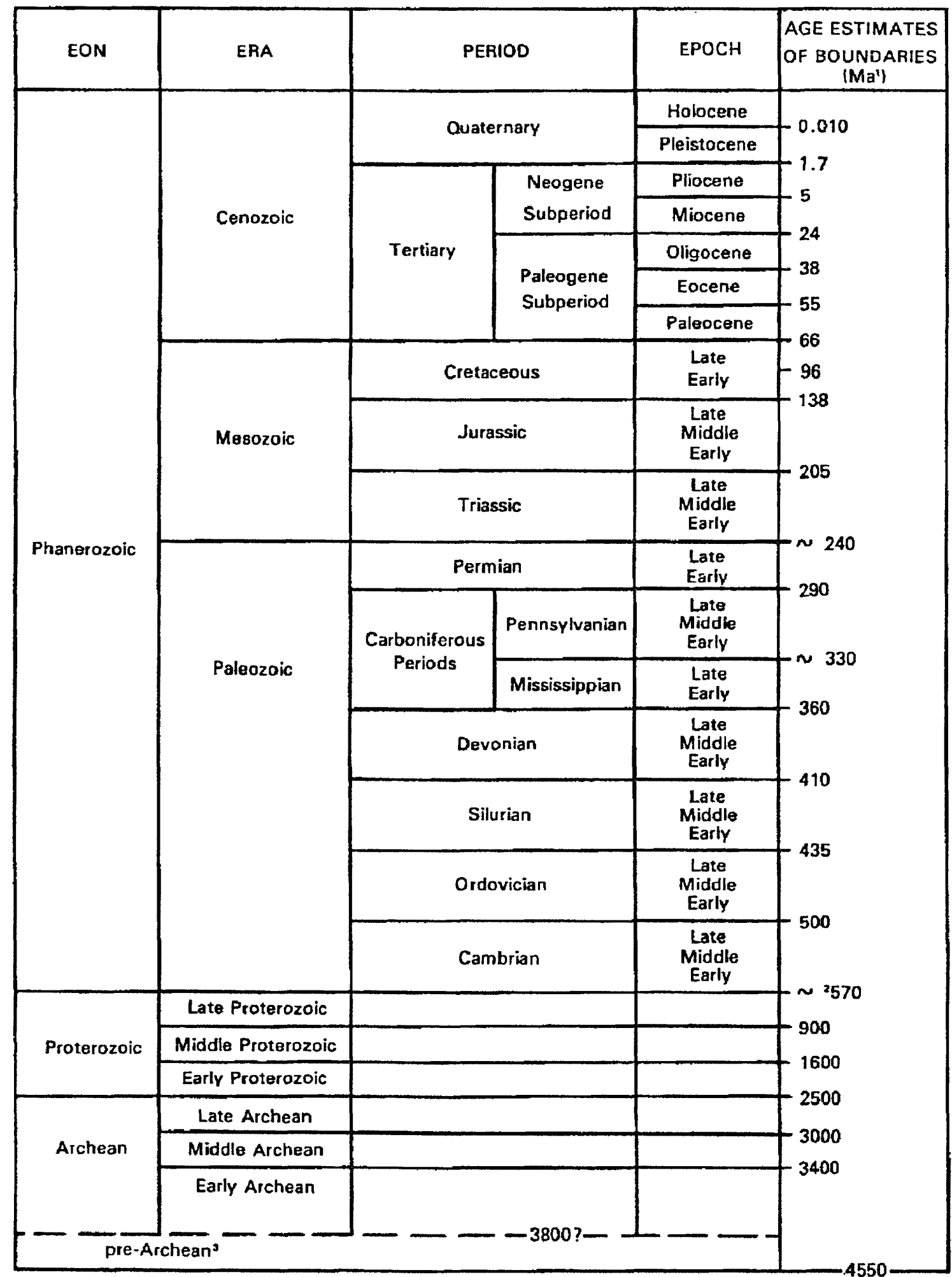

'Millions of years prior to A.D. 1950.

${ }^{2}$ Rocks older than $570 \mathrm{~m}$.. . also called Precambian, a time term without specilic rank.

Jinformal time term without specific rank. 


\section{Mineral Resources of Wilderness Study Areas- Southwestern Montana}

This volume was published as

separate chapters A-E

U.S. GEOLOGICAL SURVEY BULLETIN 1724 
U.S. DEPARTMENT OF THE INTERIOR MANUEL LUJAN, JR., Secretary

U.S. GEOLOGICAL SURVEY

Dallas L. Peck, Director

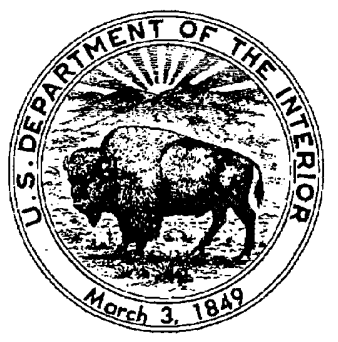




\section{CONTENTS}

[Letters designate the chapters]

(A) Mineral resources of the Ruby Mountains Wilderness Study Area, Madison County, Montana, by R.G. Tysdal, G.K. Lee, J.H. Hassemer, W.F. Hanna, and S.W. Schmauch, with a section on Talc by R.B. Berg

(B) Mineral resources of the Blacktail Mountains Wilderness Study Area, Beaverhead County, Montana, by R.G. Tysdal, G.K. Lee, J.H. Hassemer, W.F. Hanna, and J.R. Benham

(C) Mineral resources of the Farlin Creek Wilderness Study Area, Beaverhead County, Montana, by R.C. Pearson, J.H. Hassemer, W.F. Hanna, D.B. Hoover, H.A. Pierce, and S.W. Schmauch

(D) Mineral resources of the Quigg West Wilderness Study Area, Granite County, Montana, by R.G. Tysdal, W.F. Hanna, and D.O. Capstick

(E) Mineral resources of the Sleeping Giant Wilderness Study Area, Lewis and Clark County, Montana, by R.G. Tysdal, M.W. Reynolds, R.R. Carlson, M.D. Kleinkopf, L.C. Rowan, and T.J. Peters 


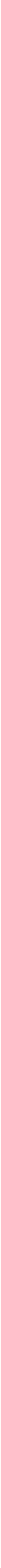




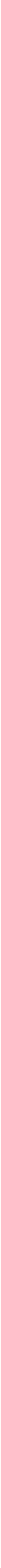




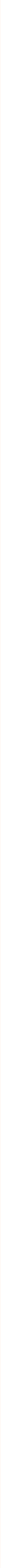

